Wrana, Javier y Martín, Jose María. Eurozone sovereign bonds and rating assessments: impact on volatility.

\title{
EUROZONE SOVEREIGN BONDS AND RATING ASSESSMENTS: IMPACT ON VOLATILITY
}

\author{
WRANA, JAVIER \\ Universidad Rey Juan Carlos \\ javier.wrana@urjc.es \\ MARTIN FLORES, JOSE MARÍA \\ Deloitte \\ jose.martin@coleurope.eu \\ Fecha de recepción: mayo de 2014 \\ Fecha de aceptación: agosto de 2014
}

\begin{abstract}
Rating agencies have been very active during the economic crisis and have been blamed for damaging the refinancing possibilities of the eurozone countries. Their decisions concerning sovereign bonds have been widely pointed out as one of the reasons why spreads rose dramatically between 2009 and 2012. Nonetheless, last evolutions of the sovereign spreads in countries such as Spain, Ireland or France show that sovereigns do not respond to rating assessments as extremely as they did before. Therefore, economic actors may wonder whether there has been a recent change in the trend or by contrast those assessments did not influence the volatility of the spreads, which may have been motivated by other variables. In this paper we will intend to determine to what extent S\&P announcements were drivers of higher volatility of sovereign bonds' spreads and how these effects (if any) have evolved over the economic crisis.
\end{abstract}

KEYWORDS: Rating agencies, sovereign bonds, volatility, economic crisis.

JEL: F34, G24.

\section{INTRODUCTION}

The sustainability of public finances has been widely discussed in the framework of the eurozone crisis. Since the intensification of the crisis in September 2008, 10years sovereign bonds yields increased rapidly, affecting mainly those countries whose economic fundamentals were more deteriorated. This impact is clearly observed on the widening of these countries' spreads over German Bunds. Along with the increase of the spreads, we observe a sharp rise of the volatility experienced by eurozone sovereigns, questioning their consideration as safe investment.

In this context, rating agencies played a significant role. They have been very active issuing credit risk announcements, especially in the period 2009-2013. Their announcements were accompanied by drastic jumps of sovereign yield spreads (see 
Wrana, Javier y Martín, Jose María. Eurozone sovereign bonds and rating assessments: impact on volatility.

figure 1). However, the graphs show that the timing of the announcements did not always succeed at anticipating the market trends ${ }^{1}$.

Figure 1: Evolution of sovereign spreads and S\&P rating notches ${ }^{2}$
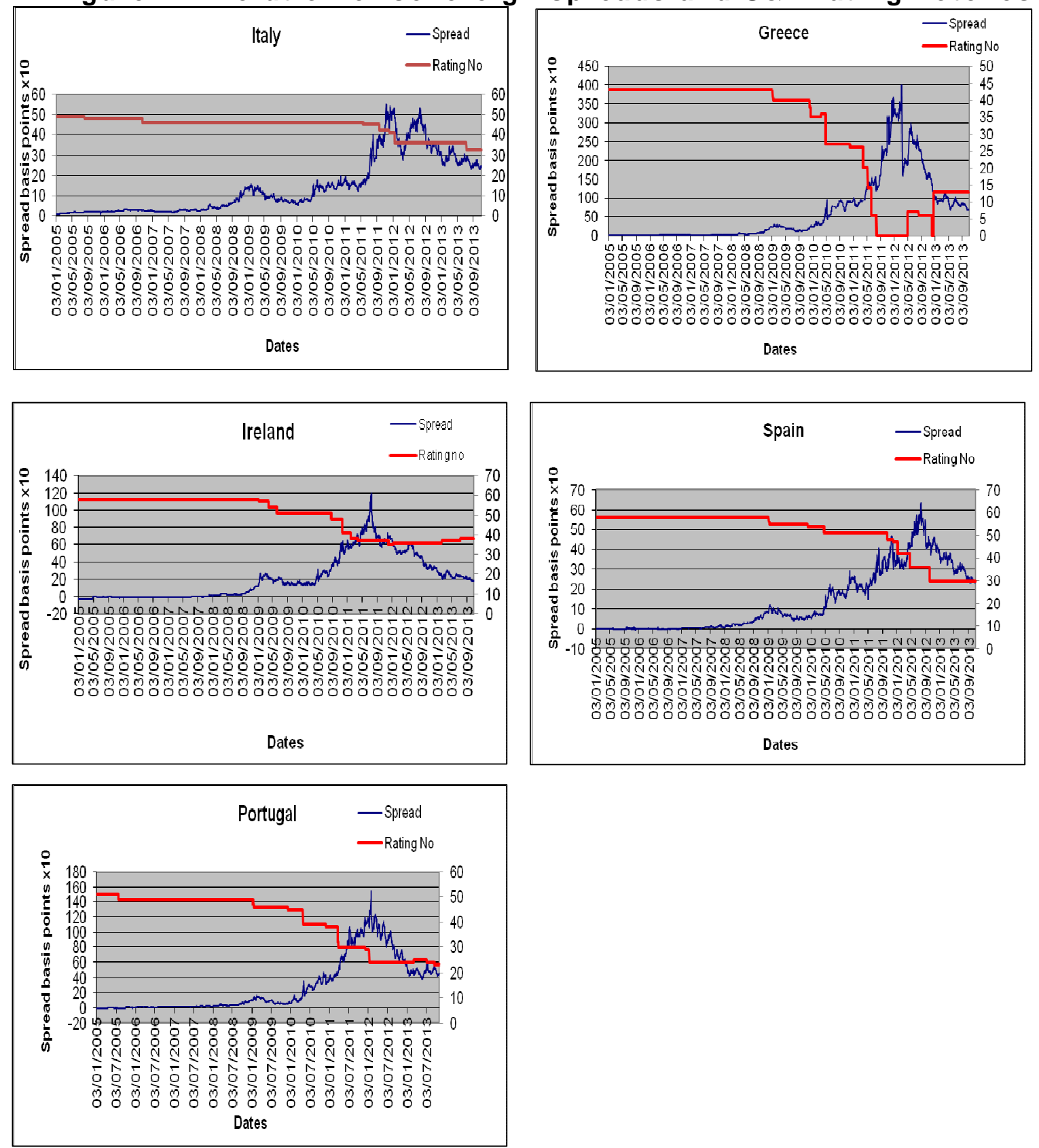

\footnotetext{
${ }^{1}$ It is worth mentioning that the reduction of sovereign spreads as from mid July 2012, notably in the cases of Spain, Ireland, Italy and Portugal and to a lesser extent for Greece, is highly motivated by the announcement made by the President of the ECB, Mario Draghi at the Global Investment Conference on the $26^{\text {th }}$ July 2012. In this conference Draghi stated that as the stress suffered by the public debt of some eurozone countries is hampering the functioning of the eurozone monetary policy, the ECB would adopt the needed measures to make it function properly and preserve the euro.

${ }^{2}$ In order to transform this qualitative data into a numerical format we have followed the approach developed by Intereconomics (2011). This analysis of the behaviour of the Credit Rating Agencies (on the right scale) consists of 58 points in which changes in outlook and watch have been considered (see appendix 1). This linear representation involves that differences of ratings match one to one with different perceptions of sovereign risk. Spreads are measured by 10 year government bonds vs German bund.
} 
Wrana, Javier y Martín, Jose María. Eurozone sovereign bonds and rating assessments: impact on volatility.

This paper will not contribute to the existent literature on whether Credit Rating Agencies provided qualitative assessments or not, but rather on their impact on the volatility of eurozone sovereigns spreads. We will intend to determine to what extent sovereign rating assessments have been drivers of excessive ("abnormal") volatility of these sovereigns.

Our study links rating agencies, eurozone sovereign debt and spreads volatility. To develop this study we have considered the announcements released by the agency Standard and Poor's and the daily yield spreads of 11 eurozone countries from March 2001 to September 2013.

There are several studies that have measured the impact of sovereign ratings on sovereign bonds; Cantor and Packer (1996), Larraín et al (1997), Reisen and von Maltzan (1998 \& 1999), Ismailescu and Kazemi (2010) and Raimbourg and Ory (2011). In the first three cases they used event study methodologies for a sample in which they mainly included emerging countries. They found evidence that rating opinions affect spreads and market volatility in certain cases. Ismailescu and Kazemi measured the impact of rating news on CDS spreads and they concluded that ratings seem to provide new information to the sovereign CDS market. Raisen and von Maltzan (1998) measured the impact of rating events on financial market volatility. They split volatility into two; bond yield spreads volatility and stock market volatility. Using event study methodologies they found that downgrading, reviews for negative outlooks and upgrading had statistically significant impact on market volatility.

Our paper brings "fresh air" to the literature related to the topic. Although some of the above mentioned papers study the impact of rating assessments on sovereign bonds yields in the context of the eurozone crisis, none of them analyze the issue from the perspective of spreads volatility. Our first objective is to conduct an event study in which we analyze the behavior of sovereign bond volatility, first within an event window of 30 days and later within the 4 days surrounding the rating events in order to determine whether abnormal volatility is observed. This choice has been motivated by the methodology used by Reisen and von Maltzan (1998), Hand et al (1992) and Bouraoui (2009). Our second objective is to observe how the influence of rating announcements on spreads volatility evolves over the eurozone crisis.

The paper is structured in four sections; second section will be devoted to a literature review as well as a description of the trends followed by sovereign bonds volatility over the period of analysis. In the third section we will perform an event study that will allow us to test both graphically and analytically whether rating announcements trigger excessive volatility in the market. We will distinguish between both types of announcements; actual rating changes and watch/outlook changes implemented by the agency Standard and Poor's over the period covered by our study. To finalize we will draw some conclusions and policy recommendations.

\section{RATING ANNOUNCEMENTS AND SOVEREIGN BONDS BEHAVIOUR}

\subsection{Related literature: impact of rating announcements on spreads}

The effects of sovereign rating news on bond risk premium have been widely studied by the economic literature. Cantor and Packer (1996) analysed the macroeconomic 
Wrana, Javier y Martín, Jose María. Eurozone sovereign bonds and rating assessments: impact on volatility.

determinants of sovereign ratings. They found that per capita income, GDP growth, inflation, fiscal balance, external debt level and default history are the main factors behind the assessments. Additionally, they used an event study to analyse the impact of rating news on sovereign spreads finding evidence that rating news affect independently market spreads, especially in the case of non-investment grade ratings; spreads increase with negative news and viceversa.

Reisen and von Maltzan (1998) associated rating events with changes in sovereign spread and financial market volatility. First, they analysed the granger-causality of rating news and changes in sovereign spreads. Then, using the same event study methodology as Cantor and Packer, they found significant impact of rating decisions on sovereign yields which was interpreted as a signal for the market about the credit worthiness of the country. In addition, they tested this impact on the volatility of sovereign bond spreads ${ }^{3}$ and stock markets. In both cases they found significant impact of negative news on volatility and no impact of positive news.

A similar working paper was published by the OECD in which Reisen and von Maltzan (1999) mainly focused on the link between rating agencies decisions and emerging countries bond spreads. They concluded that Credit Rating Agencies' opinions tend to foster boom-bust cycles in sovereign bond markets.

Larraín et al (1997) performed an event study to examine the market's assessment of the rating announcements by Moody's and S\&P in the context of the "tequila crisis". They concluded that credit rating opinions tended to lag the market instead of leading it because their assessment evidenced that rating events were anticipated by the market, especially regarding rating outlook reviews.

More recently Ismailescu and Kazemi (2010) tested through an event study methodology the reaction of CDS spreads to Credit Rating Agencies' news. They determined that rating announcements seem to provide new information to the market. Comparing to the previous literature they found that positive news have a more significant impact on sovereign CDS spreads than negative news. They based their argument on the fact that negative events have a higher probability of being predicted by the CDS market, therefore their impact is lower. In the same line, Kiff et al (2012) developed an event study to test whether rating agencies provide new information to the sovereign debt market and whether certification services matter. They determined that there is a change in sovereign CDS spreads in the expected direction that led to a significant widening of the risk premia by about 37 basis points on the event day and immediately after the event.

Afonso, Furceri and Gomes (2011) tested the impact of rating announcements on CDS spreads and yield spreads for 24 European Union countries. They concluded that $\mathrm{EMU}^{4}$ and non-EMU CDS spreads responded similarly to rating news. Positive rating news triggered weak and non significant changes in CDS spread, whereas negative news increase spreads considerably. Their event study technique only found statistically significant market movements on eurozone countries upon negative S\&P announcements.

\footnotetext{
${ }^{3}$ Spreads over American 10 year Treasury.

${ }^{4}$ EMU stands for European Monetary Union.
} 
Wrana, Javier y Martín, Jose María. Eurozone sovereign bonds and rating assessments: impact on volatility.

Raimbourg and Ory (2011) developed an empirical investigation of the effect of downgrades and negative outlooks on European sovereign bond spreads. They used an alternative methodology to measure the significant impact, Perron structural break test. They came to the conclusion that the opinions issued by the three leading rating agencies are not "harmful" for the market.

Gande and Pasley (2005) tested the impact of rating news on sovereign bond yield spreads from a different point of view. They checked the "announcement spillovers" that rating agencies news may trigger over the period $1991-2000$. They include in their sample various worldwide countries that issued public debt denominated in dollars. They found significant impact of rating events on both affected country spreads and other countries' spreads. One notch downgrade was associated with an average increase of 12 basis points of the risk premia of non-downgraded countries.

Regarding news spillovers as well, Arezki et al (2011) analysed this phenomenon in the context of the European sovereign debt crisis. They found contagion across different countries. CDS spreads from one country may respond to rating events from another State. This addressed important regulatory implications about the ability of rating agencies to boost financial instability.

Metiu (2011a:7) investigated a question similar to the one of the two previous cited documents in the context of the EMU crisis. He showed that "sovereign debt crisis in small open economies may become systemically important due to the high degree of integration between government bond markets". He found a significant impact of rating news on sovereign yield premia volatility. He captures the asymmetric causality effect of rating news on volatility through an ARMA - GARCH model, given by the coefficient $\psi_{j}$ and $\sigma_{j, t}^{2}$ referred to an estimation of the time varying volatility.

$$
\sigma_{j, t}^{2}=\omega_{j}+\gamma_{j} \epsilon_{j, t-1}^{2}+\kappa_{j} \sigma_{j, t-1}^{2}+\psi_{j} \epsilon_{j, t-1}^{2} I_{j, t-1}
$$

He determined that an unexpected decrease of spreads raises the volatility of the sovereign premia less than an expected increase of spreads.

More recently, a working paper published by the ECB analyse the impact of sovereign bonds assessments performed by rating agencies in the context of the eurozone sovereign crisis. De Santis (2012) deals with the impact of rating events on the eurozone countries that presented more deteriorated public finances (so-called PIIGS ${ }^{5}$ ) in the period 2008-2011. He found that country-specific credit rating is one of the factors that can explain the developments in sovereign spreads mainly for those countries presenting more deteriorated economic fundamentals, although they are also influenced by the existence of spillovers from other eurozone countries (i.e. Greece). He also finds evidence that spreads for Austria, Finland and the Netherlands depend on the higher demand on German bonds during the crisis (flight to quality) and not on rating events or lack of liquidity.

\footnotetext{
Although the acronym PIIGs has been widely stated in the economic literature pointing at the eurozone countries (Portugal, Ireland, Spain, Greece) whose public finances were not balanced, it is worth mentioning that even if Spain has been included in this group since the beginning of the crisis it is only after Q4 2010 when Spanish debt to GDP ratio goes above the limit established by the Stability and Growth Pact, 60\%. Spain has also been a fully compliant with this Pact in terms of deficit to GDP (3\%) and public debt to GDP before the beginning of the financial crisis.
} 
Wrana, Javier y Martín, Jose María. Eurozone sovereign bonds and rating assessments: impact on volatility.

\subsection{Rating announcements as drivers of volatility}

In this section we analyse the evolution of sovereign spreads volatility and the factors that may link historical volatility with credit rating announcements.

Figure 2: Bond yield spreads volatility (Greece excluded) ${ }^{6}$

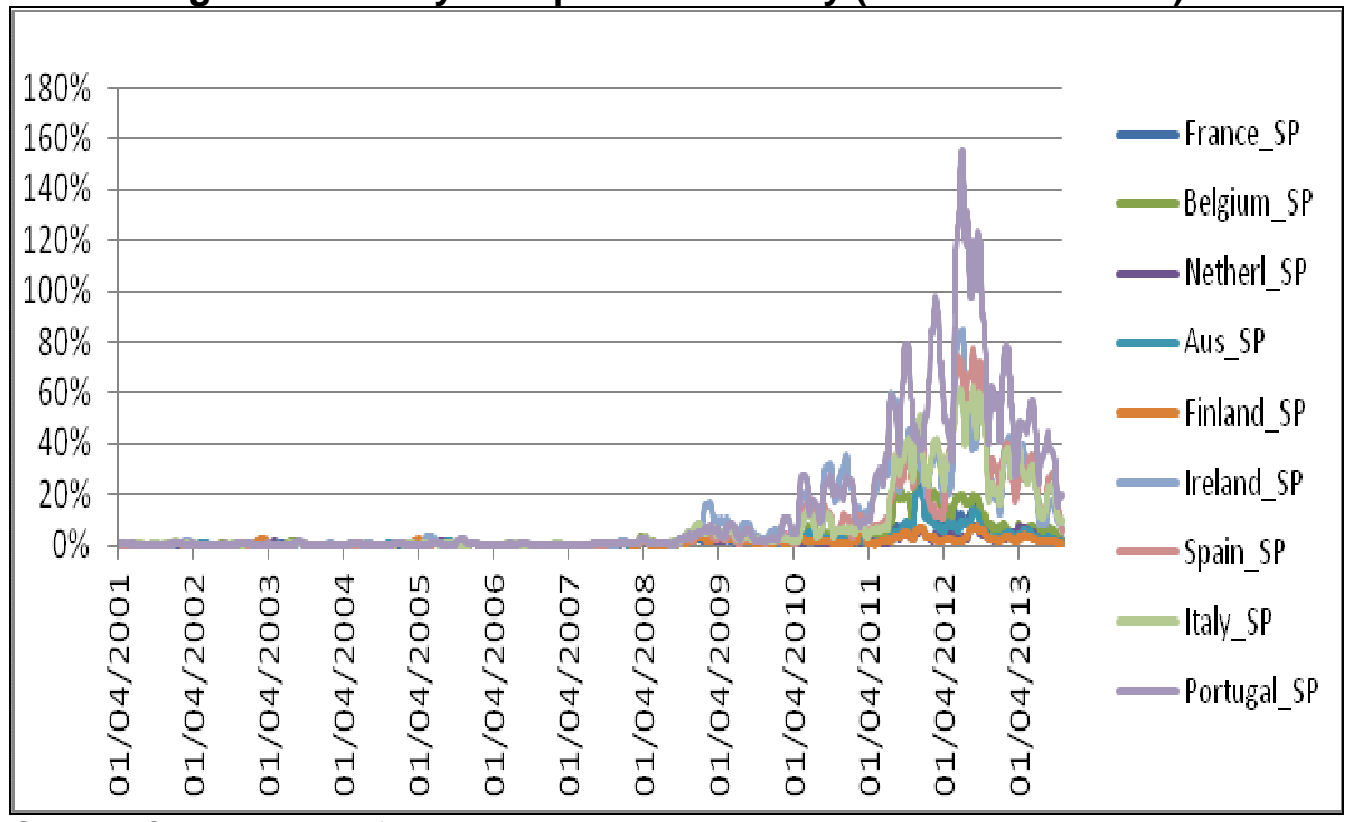

Source: Compiled data from Financial Times.

We observe in figure 2 that up to mid 2007, volatility of eurozone sovereign bonds was fairly low. Such a low levels of volatility and the fact that spreads were just few basis points above German bund made all eurozone sovereigns be perceived as roughly equivalent. However, spreads started widening in mid-2008 and the situation worsened as of the beginning of the financial crisis.

Sovereign crisis distorted the perception of investors about credit risk, which was reinforced by the increasing trend followed by volatility. In circumstances of low volatility, higher yields may compensate for higher risk, and bonds of high-spread countries could still be attractive ${ }^{7}$. But in such a context of high volatility, these greater yields are not sufficient to compensate for more risk (IMF, 2011). Since the beginning of 2010, volatility of high spread eurozone sovereign bonds was well above the level of those countries with low spreads (see figure 3) what had an obvious negative impact on their attractiveness; increasing volatility implies that daily movements in bond yields (or prices) are less predictable what means greater risk from holding these bonds ${ }^{8}$ (Sosvilla and Morales, 2011).

From a macroeconomic point of view, the increase of uncertainty has a negative impact on the economy. First, government debt represents a relevant percentage

\footnotetext{
${ }^{6}$ Historical volatility computed as 30 days moving average of the change in sovereign debt spread. Volatility must be then understood as a measure of the changes in bond yields independently from their sign.

${ }^{7}$ Appendix 6 a) shows that wider spread are associated with higher spread volatility.

8 "An increase in volatility raises the likelihood, for a specific asset/liability, that asset value will fall to the default point” (Manning, 2004:13).
} 
Wrana, Javier y Martín, Jose María. Eurozone sovereign bonds and rating assessments: impact on volatility.

among the financial assets and higher volatility of sovereign spreads can translate into more uncertainty in general expectations. In addition, it also undermines the value of the securities issued by local banks and companies due to the fact treasury bonds have commonly been considered as a benchmark risk free asset (Masciandaro, 2011). Moreover, sovereign bonds are held by banks, companies and private investors, mainly national but international as well, so higher bond spread volatility has important systemic consequences.

Figure 3 : Eurozone Treasury spreads over German Bunds, and volatility

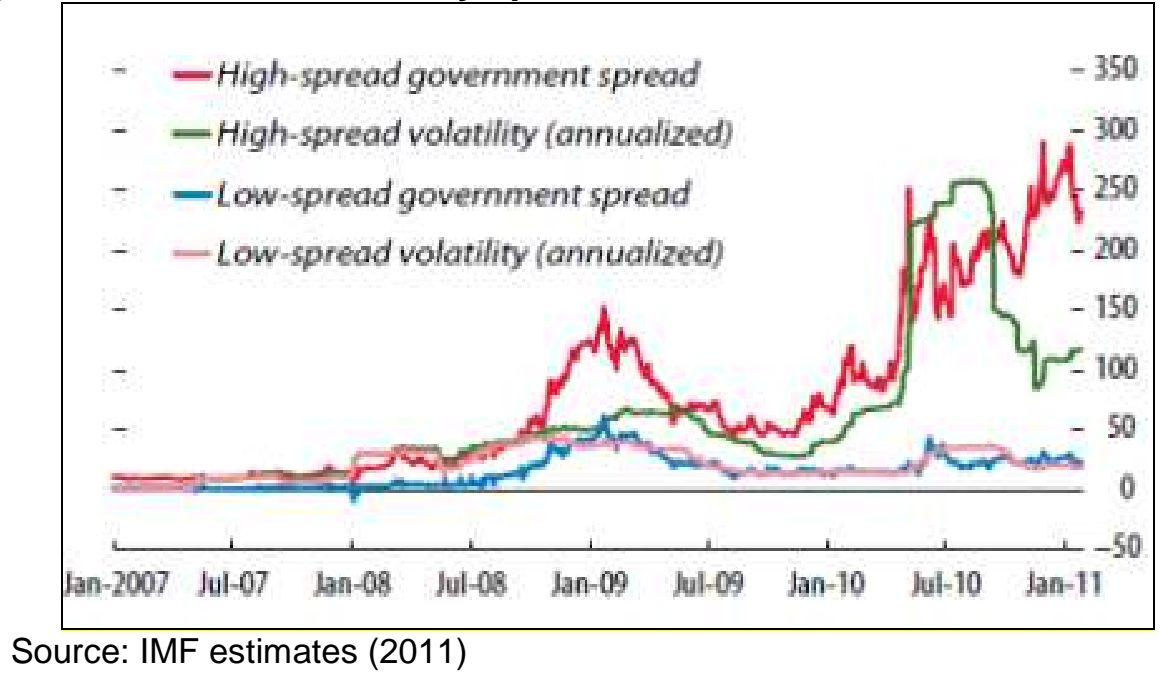

As credit ratings are a measure of the credit capacity (or willingness to pay), we can affirm that volatility of yield spreads is potentially influenced by rating announcements (Metiu, 2011). A deterioration of the sovereign credit quality causes a reduction of the number of potential buyers for these bonds, triggering spread movements and difficulties to roll-over debt issuances (Whelan, 2011).

Financial literature has shown that credit ratings appear to influence sovereign yields in addition to their correlation with other publicly available information (Cantor and Packer, 1996:34 ${ }^{\text {; }}$ Reisen von Maltzan, 1999 and Metiu, 2011). Most of the announcements made by the Credit Rating Agencies have been concentrated in the period 2009-2013. Of course, rating news have not been the only driver of volatility since the deterioration of public finances and other news have also played an important role. As it was empirically established by Borio and McCuley (1996:75) fiscal disequilibria enhance yield volatility, but it is not the only factor; news related to sovereign bonds also explain variations.

Certain elements attached to rating assessments may contribute to raise volatility upon their announcements. The main channels that we have found in the literature are:

\section{a) Attachment of ratings to regulation}

Ratings are embedded in regulatory capital and thresholds. Under prudential regulation rules, banks are allowed to hold less capital or own reserves against highly

\footnotetext{
${ }^{9}$ In their study, taking into account rating events from Moody's and S\&P they find that their single rating variable explains $92 \%$ of the variation in spreads.
} 
Wrana, Javier y Martín, Jose María. Eurozone sovereign bonds and rating assessments: impact on volatility.

rated securities within their balance sheet ${ }^{10}$ having to increase its capital in case of higher credit risk (lower rating) is assigned to its holdings.

For instance, Basel II rules allowed for two approaches to measure credit risk; the standard one that relies on rating assessments by the rating agencies and the internal rating based system (IRB). Although banks must have their own methodologies to assess credit risk from counterparties or securities, there is a high degree of reliance on external assessments (BIS, 2010:52) (Sy, 2009:10).

Other example of attachment of ratings to regulation is the minimum collateral requirement of the ECB. The ECB determines through a rating grade scale which assets can be used as collateral for money market operations ${ }^{11}$ (ECB, 2012).

Sometimes, ratings are linked to financial contracts. The application of rating-based models is sometimes due to the fact that valuing securities may be tied to ratings such as swap protections against downgrading (Duffie and Kenneth, 2003:139). This may lead to further collateral calls or force selling by fund managers. In other cases the investment mandate of the institution (life insurer, pension funds, etc.) prevents managers from investing in securities that are under the eligibility criteria that is often set through a rating issued by one of the leading Credit Rating Agencies (Deb et al, 2011).

Figure 4: Foreign investor share of total sovereign debt. Percentages. 2009-2011.

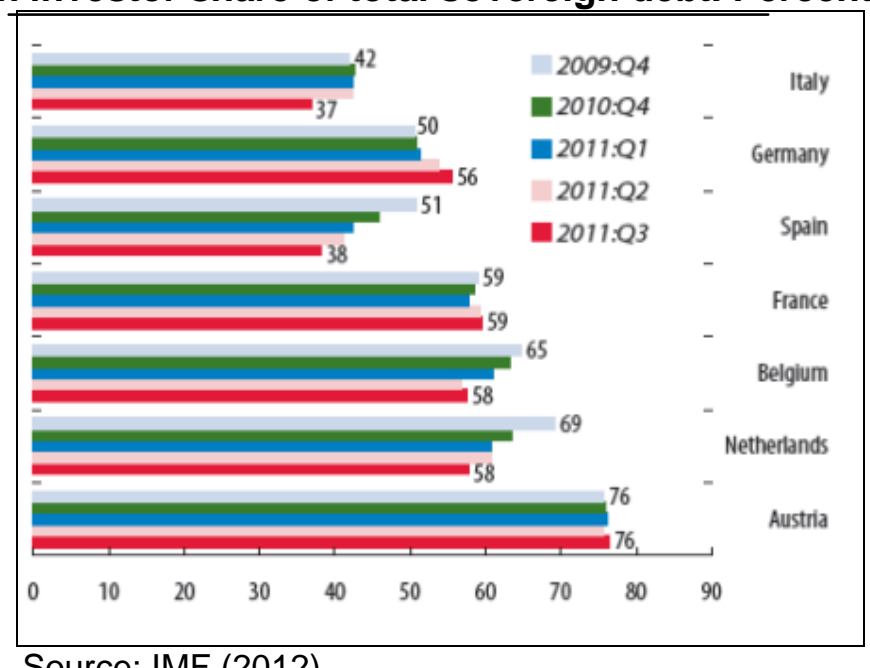

Source: IMF (2012)

This "hardwiring" of ratings into regulation grants more systemic importance to Credit Rating Agencies creating a sort of "license effect" (Masciandro, 2011a). The relevance of the rating announcement plays an important role and makes sovereign debt yields and prices be sensitive to rating events. In the context of sovereign bonds this fact mainly affects to those that are downgrading towards the speculative grade. Downgrading may cause sell offs because investors will perceive these bonds as distressed. Buy and hold investors will try to rebalance their portfolios in order to reduce their exposure and meet the mentioned requirements; price movements will

\footnotetext{
${ }^{10}$ See appendix 4

${ }^{11}$ See appendix 7.
} 
Wrana, Javier y Martín, Jose María. Eurozone sovereign bonds and rating assessments: impact on volatility.

also be translated into more capital requirements. This so-called "cliff effect"12 after the rating announcement will trigger large price movements and greater yield volatility meaning higher market uncertainty. This higher volatility of returns will make sovereign bonds less attractive and consequently market risk premia will tend to increase (IMF, 2012). This uncertainty led to a "flight for quality" that took place in the eurozone during the economic crisis. Foreign banks started reducing their exposure to sovereign debt stocks from countries that had been heavily downgrade (Italy, Spain, Belgium - figure 4) during 2010 and 2011 (IMF, 2012).

\section{b) Communication effect}

The communication policy of the rating announcements can be another driver of bond spreads volatility. Although empirical evidence has not been found, the importance of communication methods in the release of opinions by Credit Rating Agencies has been highlighted by some authors and institutional reports ${ }^{13}$.

An example of the impact of communication strategies on market behaviour can be found in different events such as central bank governor speeches, monthly unemployment figures or monthly inflation. The same type of analysis could be done for rating agencies news. As stated Masciandro (2011b) these are the main features of the communication of rating events:

- First, the system of symbols (AAA, AA, AA-, etc.) is easy to understand by market participants regardless of their level of financial literacy. This fact does not require them to go into further analysis when they receive the announcement and market actions may be immediate.

- Rating news are often communicated when markets are open. This may trigger instant reactions in the trading venues translated into massive sell-offs which may lead to higher market volatility.

- Despite most of the rating changes are preceded by outlooks or credit watches reviews, rating actions are not always foreseen. Since there is not a fixed schedule of rating announcements, sovereign rating announcements are not always anticipated. Even if they are expected they may trigger greater volatility; especially when they are very severe (i.e. downgrades by more than 1 notch ${ }^{14}$ ).

\section{DATA}

\subsection{Sovereign ratings}

Rating notations are assessments of the ability of the sovereign bond issuer to pay back capital and interests. The different notches represent a rating grade, with the

\footnotetext{
${ }^{12}$ Cliff effect is a concept widely use in the economic literature to refer to the negative effects that a rating downgrade has on the cost of funding of the country downgraded. Downgrades trigger sudden actions that may impose funding and liquidity difficulties on the country affected.

${ }^{13}$ See Masciandro (2011a) and EU Commission (2010).

14 The economic press has often stated the surprising component of sovereign rating news. Some examples can be found in the links below:

http://www.corriere.it/International/english/articoli/2011/09/20/surprise-downgrade-for-italy.shtml

http://www.reuters.com/article/video/idUSTRE7B30AO20111206? videoId=226356194

http://www.iol.co.za/business/international/surprise-at-timing-of-s-p-downgrade-1.1212981
} 
Wrana, Javier y Martín, Jose María. Eurozone sovereign bonds and rating assessments: impact on volatility.

lowest grade of default represented by a triple $A$ and speculative grade all notches below $\mathrm{BB}+$ (see table 1).

Table 1: Rating symbols and quality of sovereign debt

\begin{tabular}{|c|c|}
\hline \multicolumn{2}{|c|}{ RATING SYMBOIS FOR LONG-TERM DEBT } \\
\hline Interpretation & Standard and Poor \\
\hline \multicolumn{2}{|l|}{ INVESTMFNTI-GRADE RATINGS } \\
\hline Highest quality & AAA \\
\hline High quality & $\begin{array}{l}\mathrm{AA}+ \\
\mathrm{AA} \\
\mathrm{AA}-\end{array}$ \\
\hline Strong payment capacity & $\begin{array}{l}\mathrm{A}+ \\
\mathrm{A} \\
\mathrm{A}-\end{array}$ \\
\hline $\begin{array}{l}\text { Adequate payment } \\
\text { capacity }\end{array}$ & $\begin{array}{l}\mathrm{BBB}+ \\
\text { BBB } \\
\text { BBB- }\end{array}$ \\
\hline \multicolumn{2}{|l|}{ Specul_attVE-Grade RATinGs } \\
\hline $\begin{array}{l}\text { Likely to fulfill obliggations, } \\
\text { ongoing uncertainty }\end{array}$ & $\begin{array}{l}\mathrm{BB}+ \\
\mathrm{BB} \\
\mathrm{BB}-\end{array}$ \\
\hline High-risk obligations & $\begin{array}{l}\mathrm{B}+ \\
\mathrm{B} \\
\mathrm{B}-\end{array}$ \\
\hline
\end{tabular}

Source: Cantor and Packer (1996)

Table 2: Rating actions by 3 market competitors (2005-2011)

\begin{tabular}{|c|c|c|c|c|c|c|}
\hline & \multicolumn{3}{|c|}{$\begin{array}{l}\text { The first credit rating agency to } \\
\text { take a negative rating action }\end{array}$} & \multicolumn{3}{|c|}{$\begin{array}{l}\text { The last credit rating agency to } \\
\text { take a negative rating action }\end{array}$} \\
\hline & Fitch & Moody's & S\&P & Fitch & Moody's & S\&P \\
\hline All countries & 28 & 13 & 59 & 36 & 36 & 28 \\
\hline Advanced economies & 22 & 4 & 74 & 30 & 52 & 17 \\
\hline Emerging economies & 32 & 17 & 51 & 39 & 27 & 34 \\
\hline
\end{tabular}

Source: IMF and Kiff et al (2012)

Figure 5: Total number of sovereigns rated by the market leaders ${ }^{15}$

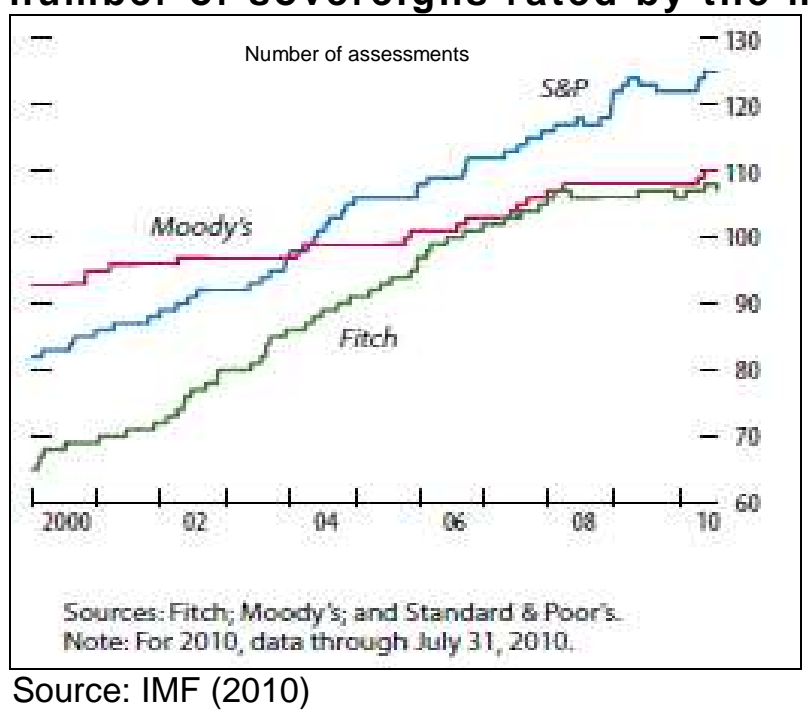

\footnotetext{
15 This figure has been obtained from IMF (2010).
} 
Wrana, Javier y Martín, Jose María. Eurozone sovereign bonds and rating assessments: impact on volatility.

Table 3: S\&P Ratings Jan. 2001 and Oct. 2013

\begin{tabular}{|lcc|}
\hline Country & $\begin{array}{c}\text { Rating S\&P } \\
\text { Jan -2001 }\end{array}$ & $\begin{array}{c}\text { Rating S\&P } \\
\text { Oct- 2013 }\end{array}$ \\
\hline Austria & $\mathrm{AAA}$ & $\mathrm{AA}+$ \\
Finland & $\mathrm{AA}+$ & $\mathrm{AAA}$ \\
Netherlands & $\mathrm{AAA}$ & $\mathrm{AAA}$ \\
France & $\mathrm{AAA}$ & $\mathrm{AA}+$ \\
Germany & $\mathrm{AAA}$ & $\mathrm{AAA}$ \\
Belgium & $\mathrm{AA}+$ & $\mathrm{AA}$ \\
Spain & $\mathrm{AA}+$ & $\mathrm{BBB}-$ \\
Portugal & $\mathrm{AA}$ & $\mathrm{BB}$ \\
Italy & $\mathrm{AA}$ & $\mathrm{BBB}$ \\
Greece & $\mathrm{A}-$ & $\mathrm{B}-$ \\
Ireland & $\mathrm{AA}+$ & $\mathrm{BBB}+$ \\
\hline Source: $\mathrm{S} \& \mathrm{P}$ & &
\end{tabular}

Our data related to credit rating assessments come from the rating agency Standard and Poor's (S\&P). We have focused on S\&P's assessments due to three reasons: First, S\&P can be considered as the market leader (table 2 and figure 5) as it is the agency that issues the highest number of sovereign ratings and is often the first credit agency to take action. Secondly, this agency has a wide availability of rating series. Thirdly, it has been widely stated by other authors (Kiff et al, 2012; Reisen and von Maltzan, 1999 and Gande and Pasley (2005)) that S\&P ratings announcements are less often anticipated by the market.

Data related to sovereign rating assessments and outlook changes were provided by the agency S\&P (appendix 2). We focus on those ratings denominated in local currency because debt placements issued by eurozone members are mostly done via competitive auctions of long maturity, fixed coupon and domestic denominated currency (De Broeck and Guscina, 2011).

\subsection{Data set}

We cover the following countries in the analysis: Austria, Belgium, Finland, France, Germany, Greece, Ireland, Italy, Netherlands, Portugal and Spain.

The reasons why we have chosen these countries are, first the wide availability of data related to these countries from the sources we had access to; secondly, all these countries have been members of the eurozone during the whole period of study; third, S\&P has issued assessments linked to each of these countries during the period, at least once (either rating changes or outlook reviews). Moreover all of them are considered developed economies and their bonds were rated as investment grade at the beginning of the period of study which allows us to set a common starting point for our analysis.

The daily data set covers the period between 1 January 2001 and 31 October 2013. Since 2001 , there have been 80 rating announcements related to these countries 
Wrana, Javier y Martín, Jose María. Eurozone sovereign bonds and rating assessments: impact on volatility.

issued by S\&P ( 40 downgrades, 12 upgrades, 2 reviews for possible upgrade and 26 reviews for possible downgrade).

The daily data for sovereign 10 year Government bond yields (end of day) comes from Financial Times database. Thus, we have worked with 3,346 observations for each country which leads to 36,806 observations. Some transformations have been performed in order to make the data workable as explained in the following section. We use 10 years government bonds spreads computed as the yield of each country's bond over the German Bund.

\section{EMPIRICAL ANALYSIS}

This section is devoted to the analysis of the impact of rating announcements on historical volatility of sovereign spreads. This analysis will cover a number of aspects such as:

1. Whether rating announcements lead to "abnormal" spread volatilities;

- To what extent these announcements are anticipated by the market;

- Whether abnormal volatility is caused either by positive or negative announcements;

2. Whether the impact of rating assessments on historical volatility varies over the crisis.

\subsection{Event Study}

We use event study method in order to test whether rating agencies announcements trigger important shifts in historical volatility of sovereign bond yields. We expect an inverse relation between rating changes and increase of the volatility (see appendix 6). This model is based on the idea that markets react immediately to announcements about the credit quality of the bonds (Mac Kinlay, 1997; pp.13). Serra (2002) identifies the following stages for the implementation of this methodology:

- Firstly we define our event and the period during which we study the event. For this purpose we will test the existence of "abnormal volatility" during the days surrounding the event; 30 days before and after the rating announcements.

- Secondly, we will base our study in the 30 days historical volatility of relative bond yield spreads. The method, as used by other authors, usually focuses on abnormal excess returns for bonds. Here, we are going to use historical volatility. As bonds may display higher risk premia after negative rating news we are going to test how this is reflected into volatility. Volatility cannot be directly observed, so it has to be calculated. We have measured volatility by using the approach developed by Reisen and Von Maltzan (1998) in which they computed historical volatility of the relative yield spreads by using a 30 -days moving average. 
Wrana, Javier y Martín, Jose María. Eurozone sovereign bonds and rating assessments: impact on volatility.

$$
\begin{aligned}
& S(X)_{t}=\sqrt{\frac{1}{(k-1)} \sum_{i=1}^{k}\left(X_{t-i+1}-\bar{X}_{t}\right)^{2}}, \\
& \text { with } \bar{X}_{t}=\frac{1}{k} \sum_{i=1}^{k} X_{t-i+1} \\
& \text { and } k=30 \text { days for yield spreads }
\end{aligned}
$$

Where $X$ is the relative yield spread. We have computed this yield spread taking the German Bund as a Benchmark ${ }^{16}$ :

$$
X=\frac{\left(\text { Yied }_{i}-\text { Yield }_{\text {Gumany }}\right)}{\text { Yield }_{\text {Germany }}}
$$

Following the recommendation by Reisen and von Maltzan (1998:13) we compute the relative spread as above. The reason why we use relative spreads is that they are more stable and fluctuate less with the general level of interest.

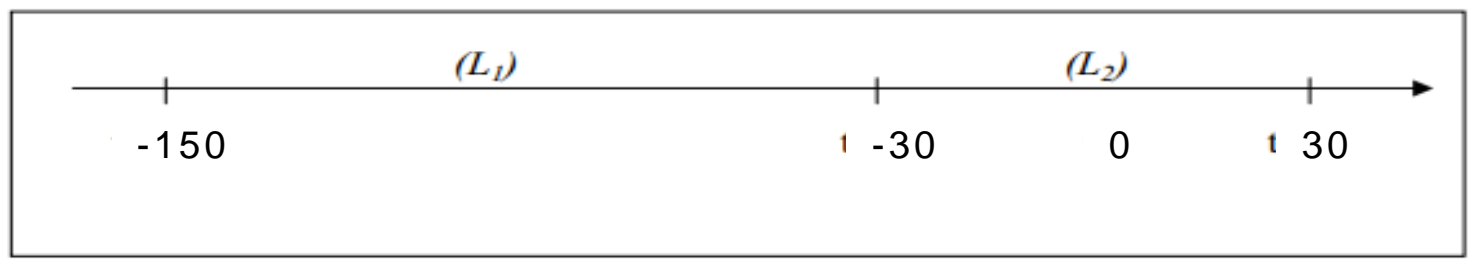

Third, we determine our estimation and event window (L2). The period of estimation (L1) mirrors what it should be considered as "normal" volatility and starts 150 days before the event as it is shown in the diagram. During the event window we will determine whether there is presence of "abnormal" volatility.

We have also ensured that both windows do not overlap each other in order to avoid a deficient estimation.

This model will allows us to test the existence of "abnormal volatility"17 the day of the rating announcement and the surrounding days. The existence of a significant excess volatility will be considered as a credit event. We will consider abnormal volatility as a positive difference between observed volatility on day $t$ and the normal volatility.

$$
A V T_{i, t}=V T_{i, t}-K T_{i, t}
$$

Where: $A V T_{i, t}=$ Abnormal volatility on day $\mathrm{t} ; \quad V T_{i, t=}=$ Volatility observed on day $\mathrm{t} ; K T_{i, t=}$ Normal volatility estimated.

\footnotetext{
${ }^{16}$ German bund is considered as the less risky Sovereign bond within the EMU.

17 The concept of excess volatility or "abnormal" volatility has been used in the financial literature in various articles such as Reisen von Maltzan (1998), Bouraoui (2009).
} 
Wrana, Javier y Martín, Jose María. Eurozone sovereign bonds and rating assessments: impact on volatility.

Where:

$$
K T_{i, t}=\frac{1}{n} \sum_{t=1}^{n} V T_{i, t}
$$

This is the average of historical volatility of the 120 days prior to the announcement (estimation period) ${ }^{18}$. This average will serve us to measure our credit event; if volatility during the event window is significantly greater than the average of the estimation period there will be presence of abnormal volatility otherwise we will consider that the volatility is not abnormal.

Then, for each type of announcement ${ }^{19}$ the event window (-30; 30 days) we will produce the contemporaneous reactions to the news by the average of the abnormal volatilities.

$$
M A V T_{i, t}=\frac{1}{n} \sum_{t=1}^{n} A V T_{i n}
$$

$M A V T_{i, t}$ is considered as the average of the abnormal volatilities for the different events that have taken place within the event windows. The parameter $n$ is equal to the number of events of the same nature ${ }^{20}$ included in the sample.

We compute the cumulative average abnormal volatility over the event window for all the announcements treated as a group.

$$
C M A V T_{i, t}=\sum_{t=1}^{n} M A V T_{i, t}
$$

Finally, the event study will allow us to test whether this estimation is significant different from zero. Our null hypothesis will be that rating news does not lead to abnormal bond yield volatility. Alternatively, a rejection of the null will mean that the announcements made by Standard \& Poor's are associated with excess volatility, thus the evolution of the bond yield volatility around the date of the announcement is different from its "normal" level.

$H_{0}=$ Absence of abnormal volatility

$H_{1}=$ Presence of abnormal volatility

In order to test our hypothesis we perform a t-test with $\mathrm{n}-1$ degrees of freedom following the approach of Holthausen and Leftwich (1992:740):

\footnotetext{
${ }^{18}$ Mackinlay (1997; pp. 15) mentions in his article that an efficient estimation window has to be at least 120 day prior to the event and cannot overlap the event window to prevent the event from influencing the normal parameters.

${ }^{19}$ We will distinguish between rating changes and changes in outlook.

${ }^{20}$ We distinguish between outlook reviews and actual upgrade or downgrade.
} 
Wrana, Javier y Martín, Jose María. Eurozone sovereign bonds and rating assessments: impact on volatility.

$$
\theta_{t}=\frac{C M A V T_{t}}{\frac{\sigma_{t}(C M A V T)}{\sqrt{n}}} \sim T_{n-1}
$$

Where:

$$
\frac{\sigma_{t}(C M A V T)}{\sqrt{n}}=\frac{\sqrt{\frac{1}{n-1} \sum_{i=1}^{n}\left(C M A V T_{i, t}-\overline{C M A V T}\right)^{2}}}{\sqrt{n}}
$$

In order to respect the overlapping condition stated by Mac Kinlay, 1997, we have dropped those events (see appendix 5 for details) whose event windows overlapped each other. Not removing these events from our analysis would have led to misleading results. Moreover events related to Greek bonds after February 2012 have been dropped from the analysis as well. The reason why we drop them is that Greek bonds were downgraded by the agency S\&P on 27 February 2012 to selective default grade. At that moment the ECB suspended the eligibility of Greek Sovereign bonds as collateral in the ECB's funding operations. Since that date, volatilities of Greek bonds attained extreme values, mainly due to the fact that a write off of the Greek debt was foreseen by the market. This strong oscillations led to outliers in the distribution and strong difficulties to determine whether abnormal volatility was caused by rating downgrades or the anticipation of the write off. Thus, we have dropped from the distribution rating announcements related to Greek debt as from the ECB's announcement ${ }^{21}$.

The results of our analysis are shown in table 4 and figure 6 below.

Panels in figure 6 show the changes in the level of volatility. When rating news are positive (positive reviews of outlook or upgrades) abnormal volatility is inexistent or tends to disappear. Before, during and after the implementation of rating upgrades we do observe that average abnormal volatility remains very close to or below zero. This is confirmed by the statistical analysis in table 4 where all the tests of significance of the cumulative average abnormal volatility reject the existence of abnormal volatility.

We observe that the abnormal volatility tends to disappear in the case of reviews for possible upgrades. The statistical analysis also confirms the absence of significant abnormal volatility. However the lack of a sufficient number of observations of positive events does not allow us to draw a conclusion with confidence.

In contrast, we observe the existence of abnormal volatility for negative rating news (downgrades and revisions for possible downgrade). As we can observe in table 4, we have a greater number of observations for negative events what allows us to come to more confident conclusions. Graphs in figure 6 show that there is an increase of volatility during the days prior to the implementation of the downgrade.

\footnotetext{
${ }^{21}$ Please refer to the ECB press release:

http://www.ecb.europa.eu/press/pr/date/2012/html/pr120228.en.html
} 
Wrana, Javier y Martín, Jose María. Eurozone sovereign bonds and rating assessments: impact on volatility.

Average excess volatility reaches $3.5 \%$ the day of the event. Excess volatility keeps increasing the days after the announcement, this means that the event itself may contribute to increase the volatility of bond yield spreads. Although we cannot affirm that it is the only factor that drivers excessive volatility during the aftermath of the event. We observe on the graph that the level of volatility reaches $10 \%$ above its normal level 30 days after the event.

Table 4 : Short term impact of rating announcements on spread volatility

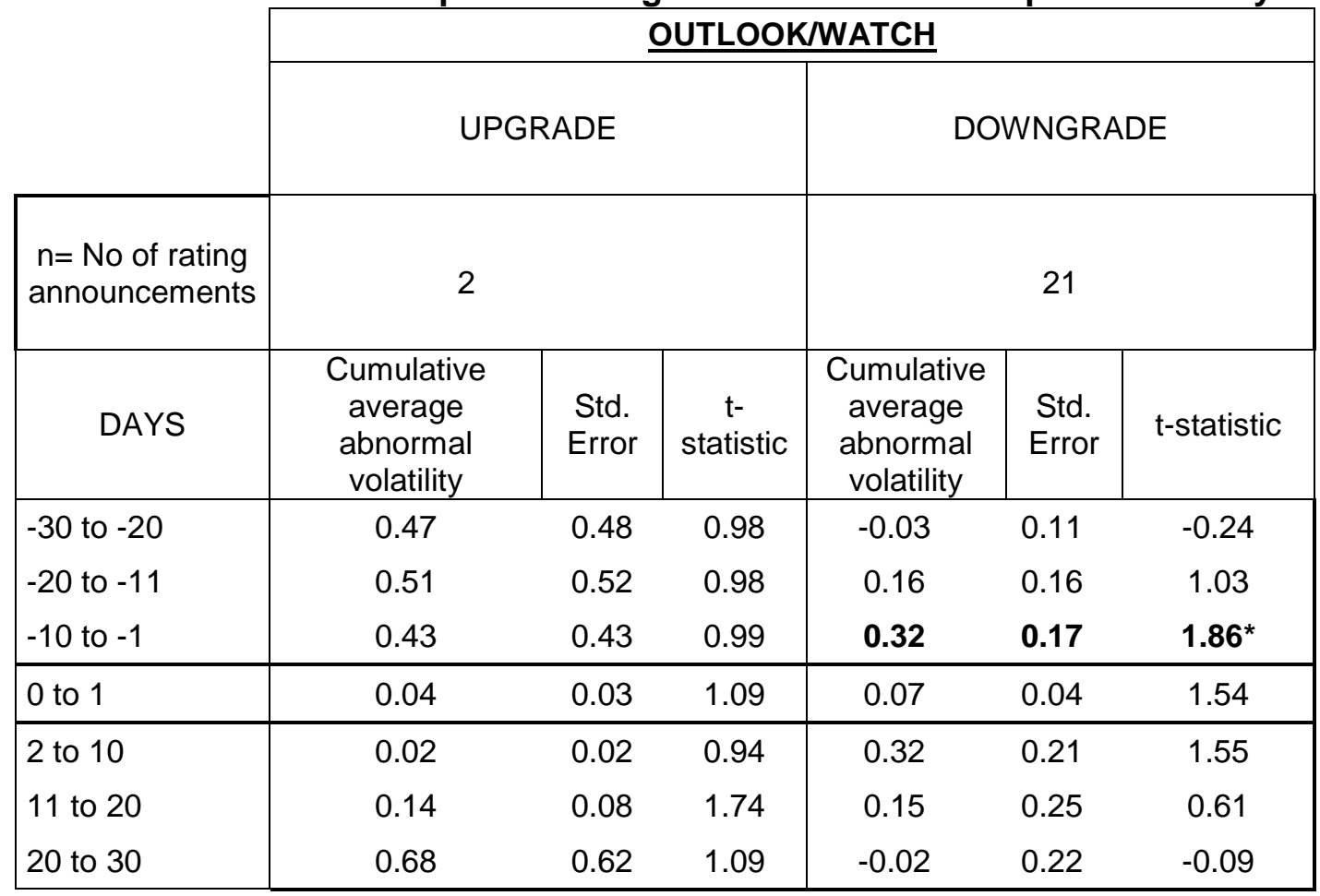

\begin{tabular}{|c|c|c|c|c|c|c|}
\hline & \multicolumn{6}{|c|}{ RATING CHANGE } \\
\hline & \multicolumn{3}{|c|}{ UPGRADE } & \multicolumn{3}{|c|}{ DOWNGRADE } \\
\hline $\begin{array}{l}n=\text { No of rating } \\
\text { announcements }\end{array}$ & \multicolumn{3}{|l|}{10} & \multicolumn{3}{|c|}{24} \\
\hline DAYS & $\begin{array}{c}\text { Cumulative } \\
\text { average } \\
\text { abnormal } \\
\text { volatility }\end{array}$ & $\begin{array}{l}\text { Std. } \\
\text { Error }\end{array}$ & $\begin{array}{c}\mathrm{t}- \\
\text { statistic }\end{array}$ & $\begin{array}{c}\text { Cumulative } \\
\text { average } \\
\text { abnormal } \\
\text { volatility }\end{array}$ & $\begin{array}{l}\text { Std. } \\
\text { Error }\end{array}$ & t-statistic \\
\hline-30 to -20 & -0.17 & 0.28 & -0.60 & 0.33 & 0.18 & $1.81^{*}$ \\
\hline-20 to -11 & -0.15 & 0.18 & -0.83 & 0.31 & 0.20 & 1.55 \\
\hline-10 to -1 & -0.38 & 0.28 & -1.39 & 0.36 & 0.23 & 1.58 \\
\hline 0 to 1 & -0.11 & 0.08 & -1.35 & 0.08 & 0.05 & 1.54 \\
\hline 2 to 10 & -0.63 & 0.44 & -1.43 & 0.41 & 0.24 & 1.69 \\
\hline 11 to 20 & -0.71 & 0.45 & -1.57 & 0.46 & 0.29 & 1.57 \\
\hline 20 to 30 & -0.63 & 0.36 & -1.76 & 0.77 & 0.38 & $2.01^{*}$ \\
\hline
\end{tabular}

${ }^{*}$ Significant $10 \%,{ }^{* *}$ Significant $5 \% ;{ }^{* * *}$ Significant $1 \%(\mathrm{n}-1$ degrees of freedom) 
Wrana, Javier y Martín, Jose María. Eurozone sovereign bonds and rating assessments: impact on volatility.

Figure 6: Rating events and excess volatility

58 rating events and sovereign yield spreads $^{22}$
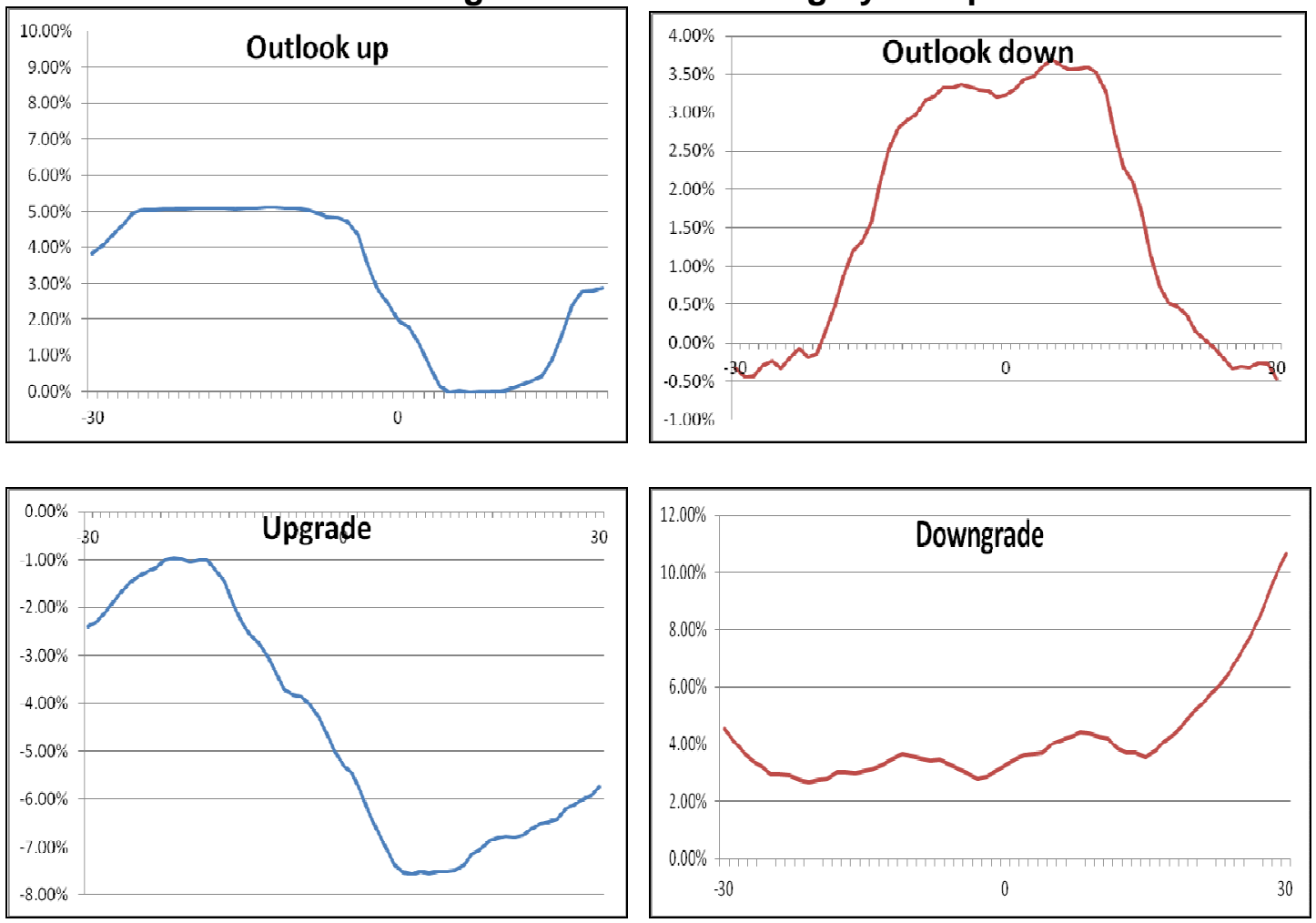

The statistical analysis shows that the estimation of the cumulative abnormal level of volatility is significant different from zero between 20 and 30 days prior to the announcement. This means that information from rating agencies is anticipated by market players. We also observe that there is a significant level of abnormal volatility in the aftermath of the event, meaning that the announcement further contributes to market instability.

We observe that the reviews for possible negative ratings may contribute to slightly increase the volatility of the bond yield spread, although this abnormal increase tends to be anticipated as well but only few days before the event, as it is shown by the statistical analysis. Volatility goes up close to $3 \%$ above the normal level of volatility the days prior to the announcement of the negative outlook review; nevertheless, it goes down again after few trading days.

In order to fully respect the assumption of not overlapping between event windows Mackinlay (1997:27), we have performed a new analysis with a shorter event window (4 days) that should lead to more accurate results. We have dropped from the analysis all these events of the same nature whose event windows overlapped (see appendix 5). Moreover, as stated above, events related to Greek bonds announced in 2012 have been removed as well. We have ended up with 34 rating downgrades,

\footnotetext{
${ }^{22}$ We have actually accounted 47 events during the period 2/1/2001 - 30/11/2011 but Portugal was downgraded twice in the same week 24th March 2011 and 29th March 2011, so we have only considered the second date for our study to avoid distortions from accounting twice the same event. Greek downgrade, $13^{\text {th }}$ June 2011 , has been excluded for the same reason. See press release:

http://online.wsj.com/article/SB 10001424052748704471904576230532021525182.html
} 
Wrana, Javier y Martín, Jose María. Eurozone sovereign bonds and rating assessments: impact on volatility.

10 upgrades, 2 reviews for possible upgrades and 23 reviews for possible downgrade. We have changed our estimation window; from 150 days to 4 days before the event and the event window as it is shown on the graph below:

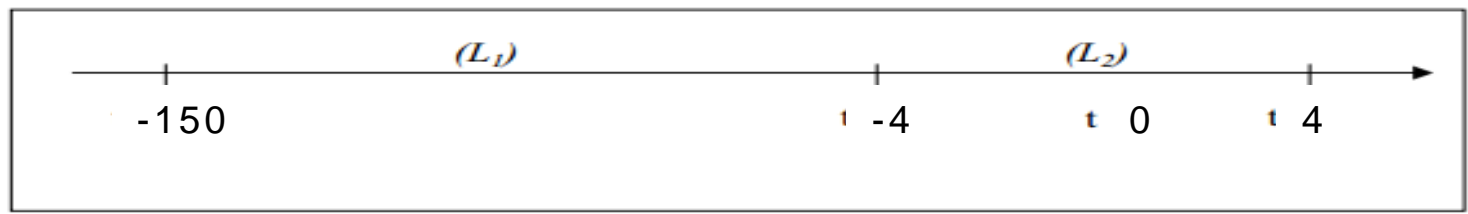

The t-test now shows that abnormal volatility is statistically significant on the event day. The increase of the estimation period leads to a more accurate estimation of normal volatility being the reason why we obtain a higher significance level. This excess volatility is also confirmed by the graphical analysis.

Table 5 : Short term impact of rating announcements on spread volatility

\begin{tabular}{|c|c|c|c|c|c|c|}
\hline & \multicolumn{6}{|c|}{ OUTLOOK/WATCH } \\
\hline & \multicolumn{3}{|c|}{ Upgrade } & \multicolumn{3}{|c|}{ Downgrades } \\
\hline $\begin{array}{c}\text { No of rating } \\
\text { announcements }\end{array}$ & \multicolumn{3}{|l|}{6} & \multicolumn{3}{|c|}{23} \\
\hline DAYS & $\begin{array}{c}\text { Cumulative } \\
\text { average } \\
\text { abnormal } \\
\text { volatility }\end{array}$ & $\begin{array}{l}\text { Std. } \\
\text { Error }\end{array}$ & $\begin{array}{c}\mathrm{t}- \\
\text { statistic }\end{array}$ & $\begin{array}{c}\text { Cumulative } \\
\text { average } \\
\text { abnormal } \\
\text { volatility }\end{array}$ & $\begin{array}{l}\text { Std. } \\
\text { Error }\end{array}$ & $\begin{array}{c}\mathrm{t}- \\
\text { statistic }\end{array}$ \\
\hline-4 to -1 & -0.07 & 0.067 & -1.08 & 0.08 & .076 & 1.109 \\
\hline 0 to 1 & -0.06 & 0.052 & -1.17 & 0.04 & .043 & 0.975 \\
\hline \multirow[t]{3}{*}{2 to 4} & -0.09 & 0.087 & -1.08 & 0.07 & .067 & 1.019 \\
\hline & \multicolumn{6}{|c|}{ RATING CHANGE } \\
\hline & \multicolumn{3}{|c|}{ Upgrade } & \multicolumn{3}{|c|}{ Downgrades } \\
\hline $\begin{array}{c}\text { No of rating } \\
\text { announcements }\end{array}$ & \multicolumn{3}{|l|}{10} & \multicolumn{3}{|c|}{34} \\
\hline DAYS & $\begin{array}{c}\text { Cumulativ } \\
\text { e average } \\
\text { abnormal } \\
\text { volatility }\end{array}$ & $\begin{array}{l}\text { Std. } \\
\text { Error }\end{array}$ & t-statistic & $\begin{array}{c}\text { Cumulativ } \\
\text { e average } \\
\text { abnormal } \\
\text { volatility }\end{array}$ & $\begin{array}{l}\text { Std. } \\
\text { Error }\end{array}$ & $\begin{array}{c}\mathrm{t}- \\
\text { statistic }\end{array}$ \\
\hline-4 to -1 & -0.16 & 0.126 & -1.301 & 0.12 & 0.067 & $1.822^{\star}$ \\
\hline 0 to 1 & -0.10 & 0.077 & -1.297 & 0.08 & 0.038 & $2.008^{*}$ \\
\hline 2 to 4 & -0.18 & 0.130 & -1.366 & 0.13 & 0.065 & $2.003^{*}$ \\
\hline
\end{tabular}

*Significant $10 \%,{ }^{* *}$ Significant $5 \% ;{ }^{* * *}$ Significant $1 \%(n-1$ degrees of freedom) 
Wrana, Javier y Martín, Jose María. Eurozone sovereign bonds and rating assessments: impact on volatility.

Regarding reviews for possible downgrade, abnormal volatility is not significant at any reasonable level of confidence neither the event date nor during the aftermath. Positive news do not lead to abnormal volatility either.

This event study presents some limitations, first we have worked with a small sample, and further research in this direction should use a larger sample. Moreover, a comparison between the different market reactions upon other agencies announcements such a Fitch or Moody's would have also been valuable in order to compare the effect of different agencies' assessments ${ }^{23}$.

Due to these reasons our conclusions must be cautioned.

Figure 7: Rating events and excess volatility.

69 observations for reviews for possible downgrades and actual downgrades

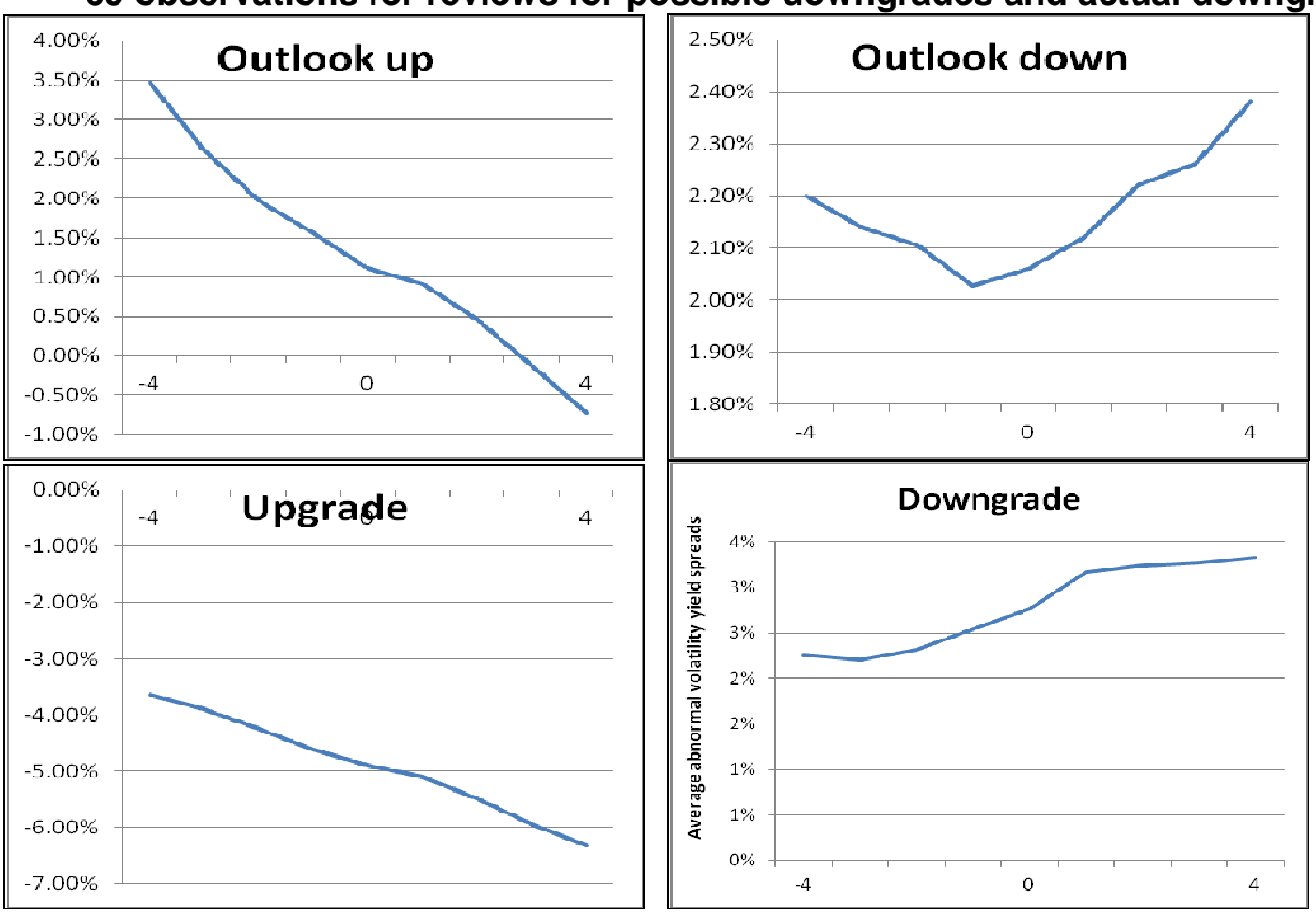

\subsection{Univariate regression}

Finally we have performed an univariate regression of volatility on rating categories for each year between 2010 and $2013^{24}$. The outcome is showed in table 6 .

Here rather than looking at the coefficients, we want to observe the evolution of the significance of ratings on volatility. Interestingly, the level of significance is lower after 2010 as it is shown by the t-statistic. This indicates a higher influence of ratings on volatility of relative yield spreads in 2010 , however, it seems that the influence of

\footnotetext{
${ }^{23}$ Please refer to Appendix 8 for details regarding the histogram of our estimation.

${ }^{24}$ For the variable rating number, we have used the rating equivalent transformation available in appendix 1 . We have included volatilities of all the countries in our sample. The method of regression is OLS, so from this table the reader should not take into account the coefficients attached to the variable since we are not trying to measure the impact of one variable on the other and the regression may be affected by some statistical flaws. We are just interested in showing how the level of significance varies.
} 
Wrana, Javier y Martín, Jose María. Eurozone sovereign bonds and rating assessments: impact on volatility.

other factors different from rating assessments is higher in the subsequent years. This confirms what we observed graphically for each event separately (see appendix 3 ). The volatility tends to increase drastically during the surrounding dates of the rating downgrades in 2010 and to less extent in 2011. This is consistent with Veron and Wolff (2011:60) who pointed that especially "after the Deauville G-20 declaration in October 2010 market developments appeared to be "driven" more by political pronouncements and less by ratings decisions". The higher significance of ratings in 2010 could also be explained by the sharp multi-notch downgradings imposed on Portugal and Greece in April 2010 pushing them to the frontier of speculative debt or even beyond.

Table 6 : Univariate regression of relative spread volatility on rating categories ${ }^{25}$. Dependent variable: Relative spread volatility

\begin{tabular}{|c|c|c|c|c|}
\hline & Coefficient & Std. Error & t-statistic & $\mathbf{R} 2$ \\
\hline \multicolumn{5}{|l|}{2010} \\
\hline Intercept & 0.683 & 0.0074 & 91.32 & 0.71 \\
\hline Rating & -0.011 & 0.000145 & $\underline{-79.88}$ & \\
\hline \multicolumn{5}{|l|}{2011} \\
\hline Intercept & 1.27 & 0.019 & 66.41 & 0.55 \\
\hline Rating & -0.022 & 0.000395 & -56.55 & \\
\hline \multicolumn{5}{|l|}{2012} \\
\hline Intercept & 2.24 & 0.0286 & 78.12 & 0.617 \\
\hline Rating & -0.042 & 0.0006 & $\underline{-64.90}$ & \\
\hline \multicolumn{5}{|l|}{2013} \\
\hline Intercept & 0.943 & 0.013 & 69.33 & 0.58 \\
\hline Rating & -0.017 & 0.003 & -55.17 & \\
\hline
\end{tabular}

\section{CONCLUSION}

We have tested to what extent rating announcements lead to abnormal volatility during the days surrounding the rating event and whether the impact of these events have been equally significant in the different periods of the last economic crisis.

Our main results show that downgradings lead to abnormal volatility before and after the event. This means that rating assessments lag the market and investors take action before sovereign rating announcements. Furthermore, once we reduce the event window, we also obtain statistically significance of abnormal volatility on the event day. This may be due to two factors, even if rating assessments are anticipated, market players wait for rating agencies' announcements before 
Wrana, Javier y Martín, Jose María. Eurozone sovereign bonds and rating assessments: impact on volatility.

reallocating their assets and the hardwiring of ratings to regulation. Moreover, ECB collateral requirements may lead to sell-offs of those sovereigns that are downgraded or pushed near or beyond speculative investment grade.

Our univariate regression shows that as from 2011 the influence of rating events on sovereign bonds spreads instability lowers, and the influence of other factors, different from rating events, on spreads movements is higher, which is consistent with the analysis of other authors such as Veron et al 2011. This may be an example of previous overreliance on rating assessments that may have contributed to the boom and boost (i.e. excessive volatility) in eurozone sovereign bond spreads over the crisis.

Financial authorities may consider solutions on how to counterbalance reliance on rating agencies assessments and internal modelling. It is well-known that the latter may lead to some conflict of interests, however the former lack from accuracy what may lead to higher volatility in the market. 
Wrana, Javier y Martín, Jose María. Eurozone sovereign bonds and rating assessments: impact on volatility.

\section{REFERENCES}

\section{Books and Academic articles}

Afonso A., D. Furceri and P. Gomes (2011) 'Sovereign credit ratings and financial markets linkages: application to European data', Working Paper 1347, European Central Bank. Frankfurt.

Bouraoui, T (2009) "The impact of stock spams on volatility". Working paper 2009-30. Université Paris Nanterre. Paris.

Borio, C.E, and McCauley R.N. (1996) "Economics of recent bond yield volatility". BIS economic papers no. 45. Monetary and economic department. Basel.

Cantor, R and Packer F (1996) "Determinants and impact of sovereign credit ratings" FRBNY Economic Policy Review. NY.

Deb P, Manning M, Murphy G, Penalver A and Toth A (2011) "Whither the credit ratings industry". Financial stability paper n.9. Bank of England

De Broeck, M and Guscina A (2011) "Government Debt Issuance in the Euro Area: The Impact of the Financial Crisis". IMF working paper WP/11/21. IMF. Washington

De la Dehesa, G (2011) "Euro Area Sovereign Debt Crisis and Rating Agencies". European Parliament policy papers. DIRECTORATE GENERAL FOR INTERNAL POLICIES. POLICY DEPARTMENT A: ECONOMIC AND SCIENTIFIC POLICIES. Brussels.

De Santis, R (2012) "The euro are sovereign debt crisis safe heaven, credit rating agencies and the spread fever from Greece, Ireland and Portugal. ECB Working Papers No. 1419. Frankfurt

Duffie, D and Kenneth, J (2003), "Credit risk: Pricing measurement and Management" . Princeton University Press, New Jersey. Chapters

Eijffinger, S (2011) "Rating Agencies - Role and Influence of their Sovereign Credit Risk Assessment in the Euro Area" European Parliament policy papers. DIRECTORATE GENERAL FOR INTERNAL POLICIES. POLICY DEPARTMENT A: ECONOMIC AND SCIENTIFIC POLICIES. Brussels.

Hand, J; Holthausen, R; Leftwich, R (1992) "The effect of bond rating agency announcements on bond and stock prices". The journal of finance. Vol 47 No 2 pp.733-752.

IMF (2010) "The uses and abuses of sovereign ratings" Global financial crisis stability review. pp. 85-112. Washington.

Ismailescu et al (2010) "The reaction of emerging market credit default swap spread to sovereign credit rating changes" Journal of banking and finance.

Kiff, $\mathrm{J}$ et al (2012) "Are rating agencies powerful? An investigation into the impact and accuracy of sovereign ratings" IMF working paper WP 12/23. IMF. Washington.

Larraín, G;Reisen, H;von Maltzan, J (1997) "Emerging market risk and Sovereign credit ratings" OECD Development Center. Technical papers no 124. Paris.

Mac Kinlay, A.C. (1997) "Event Studies in Economics and Finance". Journal of economic literature Vol. 25 pp.13-39.

Masciandaro,D (2011a) "Downgrading the downgraders?, Ratings, sovereign debt and financial market volatility. vox eu available on: vox.eu

Masciandaro, D (2011b) "What if credit rating agencies were downgraded? Ratings sovereign debt and financial market volatility". Paper serioes Paolo Baffi center of research. No 2011-107. Milano.

Manning, M (2004) "Exploring the relationship between credit spreads and default probabilities". Bank of England Working paper. num 225. London. 
Wrana, Javier y Martín, Jose María. Eurozone sovereign bonds and rating assessments: impact on volatility.

Metiu, N (2011) "The EMU in the debt distress: Contagion in sovereign bond markets" $26^{\text {th }}$ annual congress of European economic association, Oslo. Available on: http://eea-esem2011oslo.org/

Reisen, H and Van Bon Julia (1998) "Sovereign Credit Ratings, Emerging Market Risk and Financial Market Volatility " intereconomics Review of European economic Policy pp. 73-82. Hambourg

Reisen, $\mathrm{H}$ and Van Bon julia (1999) "Boom and boost and sovereign ratings". OECD Development center. Blackwell Publishers. Paris

Reisen, H (2010) "Boom, bust and sovereign ratings: Lessons for the eurozone from emerging-market ratings" available on www.vox.eu consulted 8/4/12.

Serra, A.P. (2002) "Event study tests - a brief survey -“ Working papers da FEP 117, University of Porto. Porto.

Sosvilla, S and Morales, A (2011); "Volatility in EMU sovereign bond yields: Permanent and transitory components", Instituto complutense de estudios internacionales, Working paper 06, Madrid.

Sy, A (2003), "Rating the rating agencies, currency crisis or debt crisis?, IMF Working paper 03/112, Washington.

Sy, A (2009) "The systemic regulation of Credit Rating Agencies and Rated Markets". IMF working paper 09/129. Washington.

Veron, N and Wolff, G.B. (2011) "Rating Agencies and Sovereign Credit Risk Assessment" European Parliament policy papers. DIRECTORATE GENERAL FOR INTERNAL POLICIES. POLICY DEPARTMENT A: ECONOMIC AND SCIENTIFIC POLICIES pp. 55-64. Brussels.

Whelan, K (2011) "Ratings Agency Reform: Shooting the Messengers?" European Parliament policy papers. DIRECTORATE GENERAL FOR INTERNAL POLICIES. POLICY DEPARTMENT A: ECONOMIC AND SCIENTIFIC POLICIES. Brussels.

\section{Institutional reports}

BIS (2001) "Accord Standardize risk weights". Basel committee of banking supervision. Available on http://www.bis.org/publ/bcbsca04.pdf

BIS (2010) "A global regulatory framework for more resilient banks and banking systems, December 2010. Basel committee of banking supervision. Basel. Available on: http://www.bis.org/publ/bcbs189_dec2010.pdf

BIS (2011) "Basel III a global regulatory framework for more resilient banks and banking systems" Basel committee of banking supervision. Basel. Available on: http://www.bis.org/bcbs/basel3.htm

European Commission (2010) "Public consultation on credit rating agencies", November 2010, Brussels.

European Commission (2011) "Proposal for a regulation of the European Parliament and amending Regulation (EC) No 1060/2009 on credit rating agencies", available on: http://eurlex.europa.eu/LexUriServ/LexUriServ.do?uri=COM:2011:0747:FIN:EN:PDF

European Parliament (2011a) "Rating agencies-role and influence of their sovereign credit risk assessment in the euroarea". DG internal policies. Policy department A: Economic and scientific policies. 2011-04. Brussels

European Parliament (2011b) "Credit rating agencies: future perspectives", nonlegislative resolution, available at: http://www.europarl.europa.eu/sides/

getDoc.do?type=TA\&reference=P7-TA-2011- 
Wrana, Javier y Martín, Jose María. Eurozone sovereign bonds and rating assessments: impact on volatility.

FSB (2010) "Principles for Reducing Reliance on CRA Ratings "Regulation principles. October 2010.2 available http://www.financialstabilityboard.org/publications/r_101027.pdf

IMF (2010) "The uses and abuses of sovereign ratings" Ğlobal financial crisis stability review. pp. 85-112. Global financial stability report October 2010, chapter 3. Washington.

IMF (2011) "Global financial stability report Durable Financial Stability: Getting There from Here". April 2011 Chapter 1. pp 1-74. Washington.

IMF (2012) "Global Financial Stability Report The Quest for Lasting Stability" Apil 2012. Chapter 2; Sovereigns, banks and emerging markets. pp. 17-80. Washington.

S\&P (2012a) "Sovereign Rating And Country T\&C Assessment Histories" . Historical rating series. New York.

S\&P (2013) "Sovereign Rating And Country T\&C Assessment Histories" . Historical rating series. New York.

S\&P (2012b) "Guide to credit rating essentials; What are credit ratings and how do they work? . available on: http://img.en25.com/Web/StandardandPoors/ SP_CreditRatingsGuide.pdf consulted 15th april 2012.

\section{Press releases}

Corriere.it (2011) "S\&P surprise dongrade for Italy". available on: http://www.corriere.it/International/english/articoli/2011/09/20/surprise-downgrade-foritaly.shtml

ECB (2011) "ECB announces change in eligibility of debt instruments issued or guaranteed by the Portuguese government" available on: http://www.ecb.int/press/pr/date/2011/html/pr110707_1.en.html consulted April 10 th 2012.

ECB (2012) "Eurosystem credit assessment framework". Available on: http://www.ecb.int/paym/coll/risk/ecaf/html/index.en.htm/ consulted on 25th April 2012.

ECB (2012) "Eligibility of Greek bonds used as collateral in Eurosystem monetary policy operations", ECB's press release. Available on: http://www.ecb.europa.eu/press/pr/date/2012/html/pr120228.en.html

IOL (2012) "Surprise at timing of S\&P downgrade" available on: http://www.iol.co.za/business/international/surprise-at-timing-of-s-p-downgrade1.1212981

Reuters (2011) "S\&P director defends surprise euro zone downgrade threat" available http://www.reuters.com/article/video/idUSTRE7B30AO20111206? videold=2263 56194

S\&P (2009) "Understanding Standard \& Poor's rating definitions" available on http://www.standardandpoors.com/ratings/criteria/en/us?filtername=Table\%20o f\%20Contents\&ffFix=yes. Consulted April, 12th.

WSJ (2011) "S\&P revises its criteria for sovereign ratings" available on: http://online.wsj.com/article/SB10001424052702304450604576417683104069 602.html

\section{Regulations}

Regulation (EC) No 1060/2009 on credit rating agencies that entered into full application on 7 December 2010. 
Wrana, Javier y Martín, Jose María. Eurozone sovereign bonds and rating assessments: impact on volatility.

\section{Appendix 1: Rating equivalent transformation}

\begin{tabular}{|c|c|c|}
\hline S\&P Watch changes & S\&P Rating - outlook & Rating equivalent transformation \\
\hline & AAA & 58 \\
\hline$A A+$ watch pos & AAA neg & 57 \\
\hline \multirow[t]{3}{*}{ AAA watch neg } & $A A+p o s$ & 56 \\
\hline & $\mathrm{AA}+$ & 55 \\
\hline & $A A+n e g$ & 54 \\
\hline \multirow[t]{2}{*}{$A A+$ watch neg } & AA pos & 53 \\
\hline & AA & 52 \\
\hline AA- watch pos & AA neg & 51 \\
\hline \multirow{2}{*}{ AA watch neg } & AA-pos & 50 \\
\hline & AA- & 49 \\
\hline$A+$ watch pos & AA-neg & 48 \\
\hline \multirow{2}{*}{ AA- watch neg } & $A+p o s$ & 47 \\
\hline & $A+$ & 46 \\
\hline A watch pos & $A+$ neg & 45 \\
\hline \multirow[t]{2}{*}{$A+$ watch neg } & A pos & 44 \\
\hline & A & 43 \\
\hline A- watch pos & A neg & 42 \\
\hline \multirow[t]{2}{*}{ A watch neg } & A-pos & 41 \\
\hline & A- & 40 \\
\hline BBB + watch pos & A- neg & 39 \\
\hline \multirow[t]{2}{*}{ A- watch neg } & BBB+pos & 38 \\
\hline & $\mathrm{BBB}+$ & 37 \\
\hline BBB watch pos & $\mathrm{BBB}+$ neg & 36 \\
\hline \multirow[t]{2}{*}{$\mathrm{BBB}+$ watch neg } & BBB pos & 35 \\
\hline & BBB & 34 \\
\hline BBB- watch pos & BBB neg & 33 \\
\hline \multirow[t]{2}{*}{ BBB watch neg } & BBB-pos & 32 \\
\hline & BBB- & 31 \\
\hline $\mathrm{BB}+$ watch pos & BBB- neg & 30 \\
\hline \multirow[t]{2}{*}{ BBB- watch neg } & $\mathrm{BB}+$ pos & 29 \\
\hline & $\mathrm{BB}+$ & 28 \\
\hline BB watch pos & $\mathrm{BB}+$ neg & 27 \\
\hline \multirow[t]{2}{*}{$\mathrm{BB}+$ watch neg } & BB pos & 26 \\
\hline & BB & 25 \\
\hline BB- watch pos & BB neg & 24 \\
\hline \multirow[t]{2}{*}{ BB watch neg } & BB-pos & 23 \\
\hline & BB- & 22 \\
\hline$B+$ watch pos & BB- neg & 21 \\
\hline \multirow[t]{2}{*}{ BB- watch neg } & $\mathrm{B}+$ pos & 20 \\
\hline & $\mathrm{B}+$ & 19 \\
\hline B watch pos & $B+$ neg & 18 \\
\hline \multirow[t]{2}{*}{ B+ watch neg } & B pos & 17 \\
\hline & B & 16 \\
\hline B-watch pos & B neg & 15 \\
\hline \multirow[t]{2}{*}{ B watch neg } & B-pos & 14 \\
\hline & B- & 13 \\
\hline $\mathrm{CCC}+$ watch pos & B- neg & 12 \\
\hline \multirow[t]{2}{*}{ B- watch neg } & CCC+ pos & 11 \\
\hline & $\mathrm{CCC}+$ & 10 \\
\hline CCC watch pos & CCC+ neg & 9 \\
\hline \multirow{2}{*}{$\mathrm{CCC}+$ watch neg } & CCC pos & 8 \\
\hline & CCC & 7 \\
\hline CCC- watch pos & CCC neg & 6 \\
\hline CCC watch neg & CCC-pos & 5 \\
\hline
\end{tabular}

Papeles de Europa

Vol. 27, Núm. 1 (2014): 1-32 
Wrana, Javier y Martín, Jose María. Eurozone sovereign bonds and rating assessments: impact on volatility.

\begin{tabular}{|l|c|c|} 
& CCC- & 4 \\
\hline CC watch pos & CCC- neg & 3 \\
\hline CCC- watch neg & CC pos & 2 \\
\hline & CC & 1 \\
\hline C watch pos & CC neg & 0 \\
\hline
\end{tabular}

\section{Appendix 2: S\&P Rating announcements}

S\&P rating news

\begin{tabular}{|c|c|c|c|c|c|}
\hline Country & Dates & $\begin{array}{c}\text { Type of } \\
\text { news }\end{array}$ & Country & Dates & Type of news \\
\hline France & $05 / 12 / 2011$ & $\begin{array}{c}\text { Negative } \\
\text { outlook }\end{array}$ & Italy & 05/12/2011 & $\begin{array}{c}\text { Negative } \\
\text { outlook }\end{array}$ \\
\hline France & $13 / 01 / 2013$ & Downgrade & Italy & $13 / 01 / 2012$ & Downgrade \\
\hline Belgium & $15 / 12 / 2010$ & $\begin{array}{c}\text { Negative } \\
\text { outlook }\end{array}$ & Italy & 09/07/2013 & Downgrade \\
\hline Belgium & $28 / 11 / 2011$ & Downgrade & Portugal & 29/10/2004 & $\begin{array}{c}\text { Negative } \\
\text { outlook }\end{array}$ \\
\hline Belgium & 05/12/2011 & $\begin{array}{c}\text { Negative } \\
\text { outlook }\end{array}$ & Portugal & $27 / 07 / 2005$ & Downgrade \\
\hline Belgium & $13 / 01 / 2012$ & Upgrade & Portugal & $13 / 01 / 2009$ & $\begin{array}{c}\text { Negative } \\
\text { outlook }\end{array}$ \\
\hline Netherlands & 05/12/2011 & $\begin{array}{c}\text { Negative } \\
\text { outlook }\end{array}$ & Portugal & $21 / 01 / 2009$ & Downgrade \\
\hline Netherlands & $13 / 01 / 2012$ & Downgrade & Portugal & 07/12/2009 & $\begin{array}{c}\text { Negative } \\
\text { outlook }\end{array}$ \\
\hline Austria & 05/12/2011 & $\begin{array}{c}\text { Negative } \\
\text { outlook }\end{array}$ & Portugal & $27 / 04 / 2010$ & Downgrade \\
\hline Austria & $13 / 01 / 2012$ & Downgrade & Portugal & $30 / 11 / 2010$ & $\begin{array}{l}\text { Negative } \\
\text { outlook }\end{array}$ \\
\hline Austria & $29 / 01 / 2013$ & Upgrade & Portugal & $24 / 03 / 2011$ & Downgrade \\
\hline Finland & $04 / 02 / 2002$ & Upgrade & Portugal & $29 / 03 / 2011$ & Downgrade \\
\hline Finland & 05/12/2011 & $\begin{array}{c}\text { Negative } \\
\text { outlook }\end{array}$ & Portugal & 05/12/2011 & Downgrade \\
\hline Finland & $13 / 01 / 2012$ & Downgrade & Portugal & $13 / 01 / 2012$ & Downgrade \\
\hline Finland & $14 / 01 / 2013$ & Upgrade & Portugal & $06 / 03 / 2013$ & Upgrade \\
\hline Ireland & 04/10/2001 & Upgrade & Portugal & 05/07/2013 & $\begin{array}{c}\text { Negative } \\
\text { outlook }\end{array}$ \\
\hline Ireland & 09/01/2009 & $\begin{array}{l}\text { Negative } \\
\text { outlook }\end{array}$ & Portugal & $18 / 09 / 2013$ & $\begin{array}{l}\text { Negative } \\
\text { outlook }\end{array}$ \\
\hline Ireland & $30 / 03 / 2009$ & Downgrade & Greece & $10 / 06 / 2003$ & Upgrade \\
\hline Ireland & 08/06/2009 & Downgrade & Greece & $13 / 09 / 2004$ & $\begin{array}{c}\text { Negative } \\
\text { outlook }\end{array}$ \\
\hline Ireland & $24 / 08 / 2010$ & Downgrade & Greece & $17 / 11 / 2004$ & Downgrade \\
\hline Ireland & $23 / 11 / 2010$ & Downgrade & Greece & 09/01/2009 & $\begin{array}{c}\text { Negative } \\
\text { outlook }\end{array}$ \\
\hline Ireland & $02 / 02 / 2011$ & Downgrade & Greece & $14 / 01 / 2009$ & Downgrade \\
\hline Ireland & $01 / 04 / 2011$ & Downgrade & Greece & 07/12/2009 & $\begin{array}{c}\text { Negative } \\
\text { outlook }\end{array}$ \\
\hline Ireland & 05/12/2011 & $\begin{array}{c}\text { Negative } \\
\text { outlook }\end{array}$ & Greece & $16 / 12 / 2009$ & Downgrade \\
\hline Ireland & $13 / 01 / 2012$ & Downgrade & Greece & $16 / 03 / 2010$ & Positive outlook \\
\hline Ireland & $11 / 02 / 2013$ & Upgrade & Greece & $27 / 04 / 2010$ & Downgrade \\
\hline Ireland & $12 / 07 / 2013$ & Upgrade & Greece & 02/12/2010 & $\begin{array}{c}\text { Negative } \\
\text { outlook }\end{array}$ \\
\hline
\end{tabular}


Wrana, Javier y Martín, Jose María. Eurozone sovereign bonds and rating assessments: impact on volatility.

\begin{tabular}{|l|c|c|} 
Spain & $30 / 07 / 2003$ & $\begin{array}{c}\text { Positive } \\
\text { outlook }\end{array}$ \\
\hline Spain & $13 / 12 / 2004$ & Upgrade \\
\hline Spain & $12 / 01 / 2009$ & $\begin{array}{c}\text { Negative } \\
\text { outlook }\end{array}$ \\
\hline Spain & $19 / 01 / 2009$ & Downgrade \\
\hline Spain & $09 / 12 / 2009$ & $\begin{array}{c}\text { Negative } \\
\text { outlook }\end{array}$ \\
\hline Spain & $28 / 04 / 2010$ & Downgrade \\
\hline Spain & $13 / 10 / 2011$ & Downgrade \\
\hline Spain & $05 / 12 / 2011$ & Downgrade \\
\hline Spain & $13 / 01 / 2012$ & Downgrade \\
\hline Spain & $24 / 04 / 2012$ & Downgrade \\
\hline Spain & $10 / 10 / 2012$ & Downgrade \\
\hline Italy & $15 / 01 / 2003$ & $\begin{array}{c}\text { Negative } \\
\text { outlook }\end{array}$ \\
\hline Italy & $07 / 07 / 2004$ & Downgrade \\
\hline Italy & $08 / 08 / 2005$ & $\begin{array}{c}\text { Negative } \\
\text { outlook }\end{array}$ \\
\hline Italy & $19 / 10 / 2006$ & Downgrade \\
\hline Italy & $20 / 05 / 2011$ & $\begin{array}{c}\text { Negative } \\
\text { outlook }\end{array}$ \\
\hline Italy & $20 / 09 / 2011$ & Downgrade \\
\hline
\end{tabular}

\begin{tabular}{|l|c|c|} 
Greece & $29 / 03 / 2011$ & $\begin{array}{c}\text { Negative } \\
\text { outlook }\end{array}$ \\
\hline Greece & $09 / 05 / 2011$ & $\begin{array}{c}\text { Negative } \\
\text { outlook }\end{array}$ \\
\hline Greece & $13 / 06 / 2011$ & Downgrade \\
\hline Greece & $27 / 07 / 2011$ & Downgrade \\
\hline Greece & $27 / 02 / 2012$ & $\begin{array}{c}\text { Downgrade / } \\
\text { default }\end{array}$ \\
\hline Greece & $02 / 05 / 2012$ & Upgrade \\
\hline Greece & $07 / 08 / 2012$ & Downgrade \\
\hline Greece & $05 / 12 / 2012$ & $\begin{array}{c}\text { Downgrade / } \\
\text { default }\end{array}$ \\
\hline Greece & $18 / 12 / 2012$ & Upgrade \\
\hline
\end{tabular}

Source: S\&P (2012) "Sovereign Rating and Country T\&C Assessment Histories".

\section{Appendix 3: Volatility Portuguese bonds (2008-2011)}

To illustrate this paragraph we have plot the analysis for Portugal although this trend has also been observed in other countries of the sample affected by rating changes.

Rating events and volatility Portugal between 2008 and 2011.

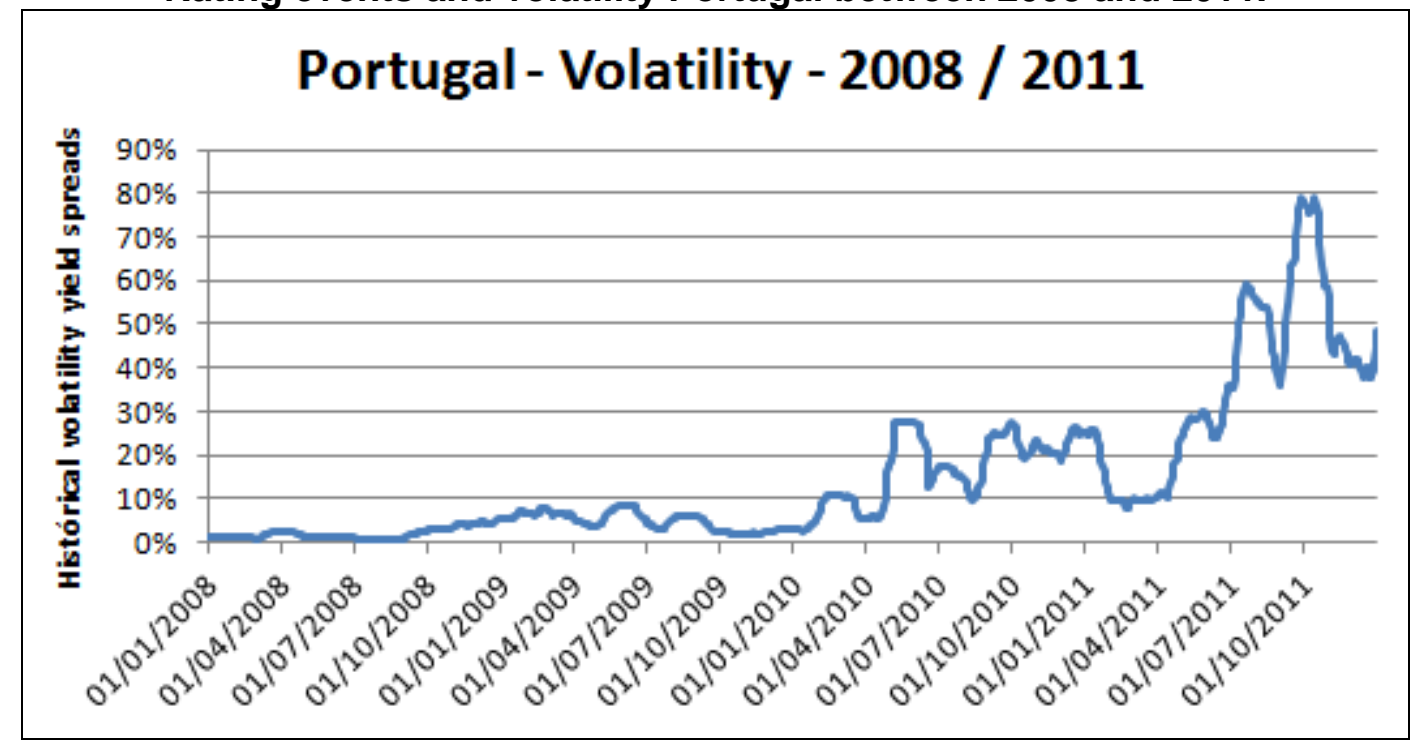


Wrana, Javier y Martín, Jose María. Eurozone sovereign bonds and rating assessments: impact on volatility.

Volatility during the 60 days ( 30 days before and after) surrounding the rating event. Downgrades
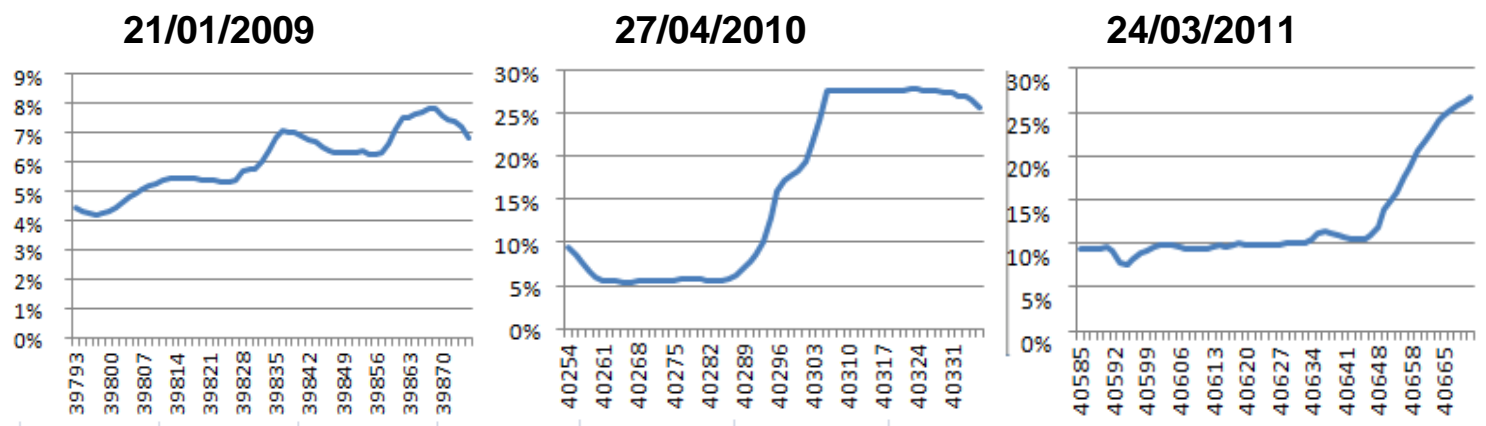

\section{Outlook changes}

$13 / 01 / 2009$

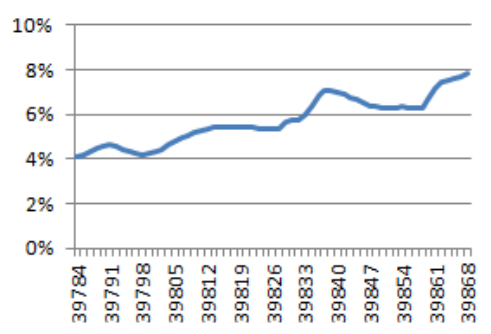

07/12/2009

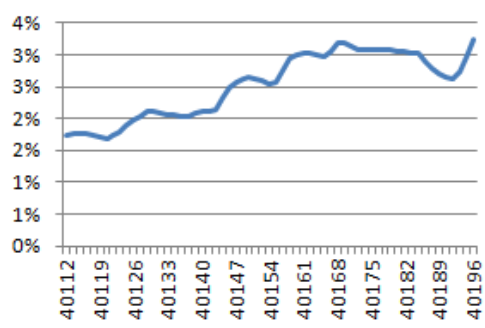

$30 / 11 / 2010$

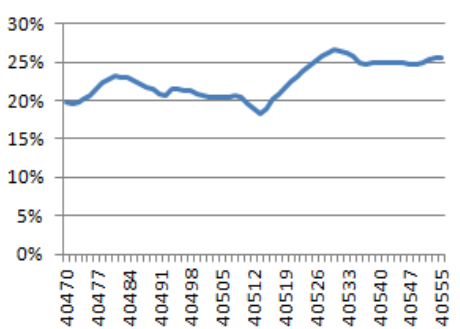

Appendix 4: Basel rating requirements and rating categories.

Basel II Sovereign Credit Weights

\begin{tabular}{|l|c|c|c|c|c|c|}
\hline $\begin{array}{l}\text { Credit } \\
\text { Assessments }\end{array}$ & $\begin{array}{c}\text { AAA to } \\
\text { AA- }\end{array}$ & $\begin{array}{c}\text { A+ to } \\
\text { A- }\end{array}$ & $\begin{array}{c}\text { BBB+ to } \\
\text { BBB- }\end{array}$ & $\begin{array}{c}\text { BB+ to } \\
\text { B- }\end{array}$ & $\begin{array}{c}\text { Below } \\
\text { B- }\end{array}$ & Unrated \\
\hline Risk Weights & $0 \%$ & $20 \%$ & $50 \%$ & $100 \%$ & $150 \%$ & $100 \%$ \\
\hline
\end{tabular}

Source: BIS 
Wrana, Javier y Martín, Jose María. Eurozone sovereign bonds and rating assessments: impact on volatility.

\section{Credit categories by rating agency}

\begin{tabular}{|c|c|c|c|}
\hline & S\&P & Moody's & Fitch \\
\hline \multicolumn{4}{|l|}{ Investment Grade } \\
\hline Highest quality, reliable, stable & AAA & Aaa & AAA \\
\hline High quality & AA & Aa & AA \\
\hline Strong payment capacity & A & A & A \\
\hline Adequate payment capacity & BBB & Baa & BBB \\
\hline \multicolumn{4}{|l|}{ Speculative Grade } \\
\hline Likely to fulfill obligations, ongoing uncertainty & BB & $\mathrm{Ba}$ & BB \\
\hline Financial situation varies considerably & B & $\mathrm{Ba}$ & B \\
\hline $\begin{array}{l}\text { Vulnerable, dependent on favorable economic } \\
\text { conditions to meet payments }\end{array}$ & $\operatorname{CCC}$ & Caa & $\mathrm{CCC}$ \\
\hline Highly vilnerable, speculative & $\infty \mathrm{C}$ & $\mathrm{Ca}$ & $C \mathrm{C}$ \\
\hline Close to default, may be in arrears & $\mathrm{C}$ & $\mathrm{C}$ & $\mathrm{C}$ \\
\hline Defaulted on obligations & D & & $\mathrm{D}$ \\
\hline \multicolumn{4}{|c|}{$\begin{array}{l}\text { Note: Within rating categories, S\&P and Fitch use plus }(+) \text { or minus }(-) \text { signs to show relative } \\
\text { standing, with } A+\text { being better than } A \text { or } A-\text {. }\end{array}$} \\
\hline \multicolumn{4}{|c|}{$\begin{array}{l}\text { Moody's uses a modifier of } 1,2 \text {, or } 3 \text { for the same purpose, w th A1 being better than A2 or A3. } \\
\text { Sources: Standard and Poor's, Moody's Investor Services, Fitch Ratings }\end{array}$} \\
\hline
\end{tabular}

Source: IMF.

\section{Appendix 5: Events dropped to avoid overlapping}

\section{0 days event window}

\begin{tabular}{|c|l|l|}
\hline \multicolumn{1}{|c|}{ Date } & Country & \multicolumn{1}{c|}{ Type of event } \\
\hline $13 / 01 / 2013$ & France & Downgrade \\
\hline $05 / 12 / 2011$ & Belgium & Negative outlook \\
\hline $13 / 01 / 2012$ & Netherlands & Downgrade \\
\hline $13 / 01 / 2012$ & Austria & Downgrade \\
\hline $13 / 01 / 2012$ & Finland & Downgrade \\
\hline $09 / 01 / 2009$ & Ireland & Negative outlook \\
\hline $13 / 01 / 2012$ & Ireland & Downgrade \\
\hline $19 / 01 / 2009$ & Spain & Downgrade \\
\hline $13 / 01 / 2012$ & Spain & Downgrade \\
\hline $13 / 01 / 2012$ & Italy & Downgrade \\
\hline $13 / 01 / 2009$ & Portugal & Negative outlook \\
\hline $29 / 03 / 2011$ & Portugal & Downgrade \\
\hline $13 / 01 / 2012$ & Portugal & Downgrade \\
\hline $14 / 01 / 2009$ & Greece & Downgrade \\
\hline $16 / 12 / 2009$ & Greece & Downgrade \\
\hline $27 / 04 / 2010$ & Greece & Downgrade \\
\hline $29 / 03 / 2011$ & Greece & Negative outlook \\
\hline $27 / 02 / 2012$ & Greece & Default grade \\
\hline $05 / 12 / 2012$ & Greece & Default grade \\
\hline $18 / 12 / 2012$ & Greece & Upgrade \\
\hline
\end{tabular}


Wrana, Javier y Martín, Jose María. Eurozone sovereign bonds and rating assessments: impact on volatility.

4 days event window

\begin{tabular}{|l|l|l|}
\hline \multicolumn{1}{|c|}{ Date } & Country & \multicolumn{1}{c|}{ Type of event } \\
\hline 05/12/2011 & Belgium & Negative outlook \\
\hline $19 / 01 / 2009$ & Spain & Downgrade \\
\hline $13 / 01 / 2009$ & Portugal & Negative outlook \\
\hline $29 / 03 / 2011$ & Portugal & Downgrade \\
\hline $14 / 01 / 2009$ & Greece & Downgrade \\
\hline $16 / 12 / 2009$ & Greece & Downgrade \\
\hline $27 / 02 / 2012$ & Greece & Default grade \\
\hline $05 / 12 / 2012$ & Greece & Default grade \\
\hline
\end{tabular}

\section{Appendix 6}

Relationship Volatility - Spreads (2001-2013).

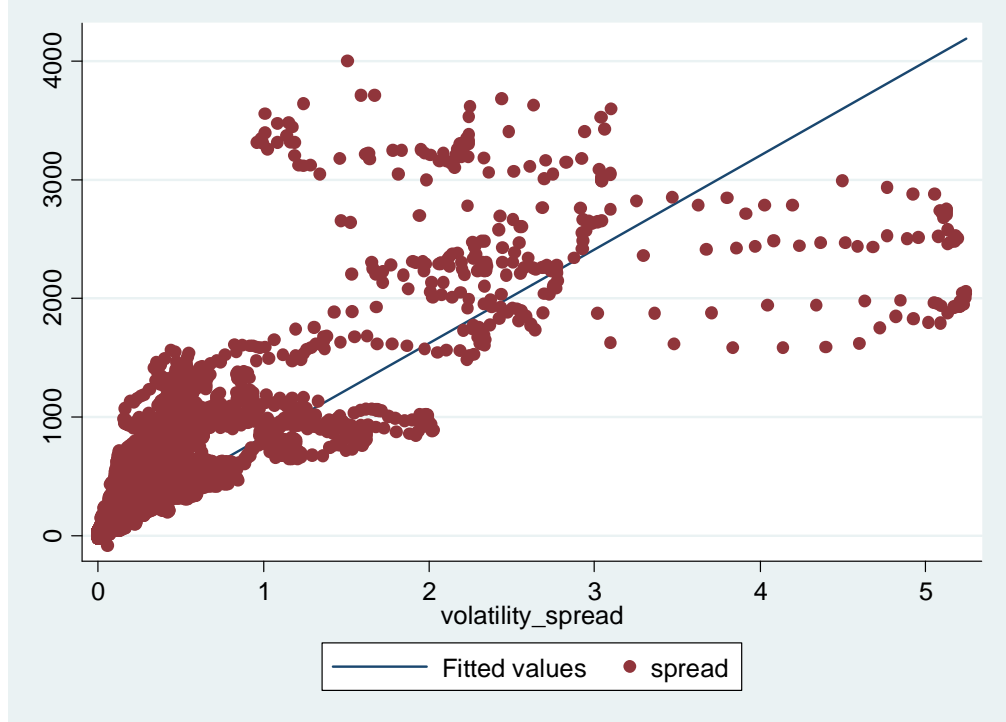

Relationship Rating number- Spread volatility

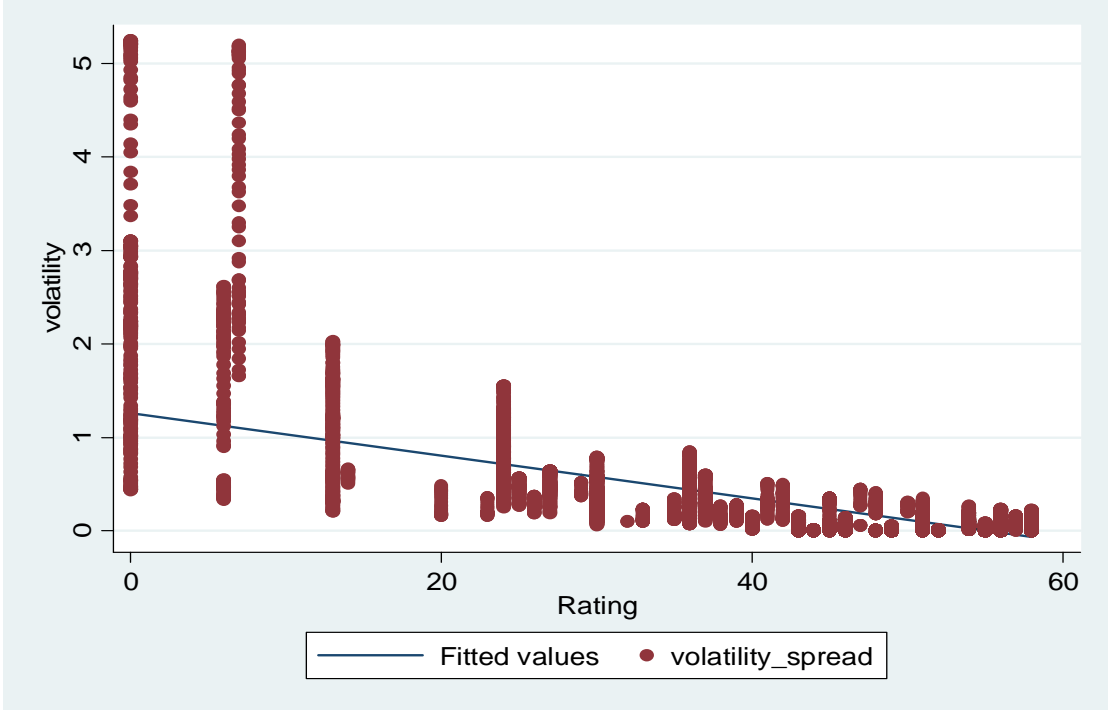


Wrana, Javier y Martín, Jose María. Eurozone sovereign bonds and rating assessments: impact on volatility.

\section{Appendix 7: List of credit assessment sources accepted by the Eurosystem.}

\begin{tabular}{|c|c|c|}
\hline $\begin{array}{c}\text { Credit } \\
\text { assessment } \\
\text { source }\end{array}$ & $\begin{array}{l}\text { Credit assessment } \\
\text { system / provider }\end{array}$ & Coverage \\
\hline \multirow[t]{4}{*}{ ECAI } & DBRS & $\begin{array}{l}\text { Eligible issuers / debtors / guarantors from EEA or } \\
\text { non-EEA G10 countries }\end{array}$ \\
\hline & FitchRatings & $\begin{array}{l}\text { Eligible issuers / debtors / guarantors from EEA or } \\
\text { non-EEA G10 countries }\end{array}$ \\
\hline & Moody's & $\begin{array}{l}\text { Eligible issuers / debtors / guarantors from EEA or } \\
\text { non-EEA G10 countries }\end{array}$ \\
\hline & Standard \& Poor's & $\begin{array}{l}\text { Eligible issuers / debtors / guarantors from EEA or } \\
\text { non-EEA G10 countries }\end{array}$ \\
\hline \multirow[t]{5}{*}{ ICAS } & Banco de España & Spanish non-financial corporations \\
\hline & Banque de France & French non-financial corporations \\
\hline & $\begin{array}{l}\text { Central Bank of } \\
\text { Ireland }\end{array}$ & $\begin{array}{l}\text { Mortgage-backed promissory notes issued by Irish } \\
\text { credit institutions }\end{array}$ \\
\hline & $\begin{array}{l}\text { Deutsche } \\
\text { Bundesbank }\end{array}$ & German non-financial corporations \\
\hline & $\begin{array}{l}\text { Oesterreichische } \\
\text { Nationalbank }\end{array}$ & Austrian non-financial corporations \\
\hline \multirow[t]{4}{*}{ RT } & $\begin{array}{l}\text { Coface Serviços } \\
\text { Portugal S.A. }\end{array}$ & $\begin{array}{l}\text { Portuguese non-financial corporations (belonging to } \\
\text { the sectors agriculture, industry and construction) }\end{array}$ \\
\hline & ICAP S.A. & Greek non-financial corporations \\
\hline & LINCE SpA & Italian non-financial corporations \\
\hline & $\begin{array}{l}\text { Creditreform Rating } \\
\text { AG }\end{array}$ & German non-financial corporations \\
\hline
\end{tabular}

Source: ECB

\begin{tabular}{|c|c|c|c|c|}
\hline \multirow{2}{*}{\multicolumn{2}{|c|}{ ECAl credit assessment }} & \multicolumn{3}{|c|}{ Credit quality steps } \\
\hline & & 1 & 2 & 3 \\
\hline \multirow{4}{*}{ Short-term } & DBRS & $\mathrm{R}-1 \mathrm{H}$ & R-1M, R-1L & $\mathrm{R}-2 \mathrm{H}, \mathrm{R}-2 \mathrm{M}$ \\
\hline & FitchRatings & $\mathrm{F} 1+$ & F1 & F2 \\
\hline & Moody's & & $P-1$ & $\mathrm{P}-2$ \\
\hline & Standard \& Poor's & $\mathrm{A}-1+$ & $A-1$ & $\mathrm{~A}-2$ \\
\hline \multirow{4}{*}{ Long-term } & DBRS & AAA/AAH/AA/AAL & AH/AVAL & $\mathrm{BBBH} / \mathrm{BBB}$ \\
\hline & FitchRatings & AAAIAA+/AAIAA- & $A+/ A / A-$ & $\mathrm{BBB}+/ \mathrm{BBB} / \mathrm{BBB}-$ \\
\hline & Moody's & $\mathrm{Aaa} / \mathrm{Aa} 1 / \mathrm{Aa} 2 / \mathrm{Aa} 3$ & $\mathrm{~A} 1 / \mathrm{A} 2 / \mathrm{A} 3$ & Baa1/Baa2/Baa3 \\
\hline & Standard \& Poor's & AAAIAA+/AAIAA- & $A+I A / A-$ & $\mathrm{BBB}+/ \mathrm{BBB} / \mathrm{BBB}-$ \\
\hline
\end{tabular}

Source: ECB 
Wrana, Javier y Martín, Jose María. Eurozone sovereign bonds and rating assessments: impact on volatility.

\section{Appendix 8: Estimated "abnormal volatility".}

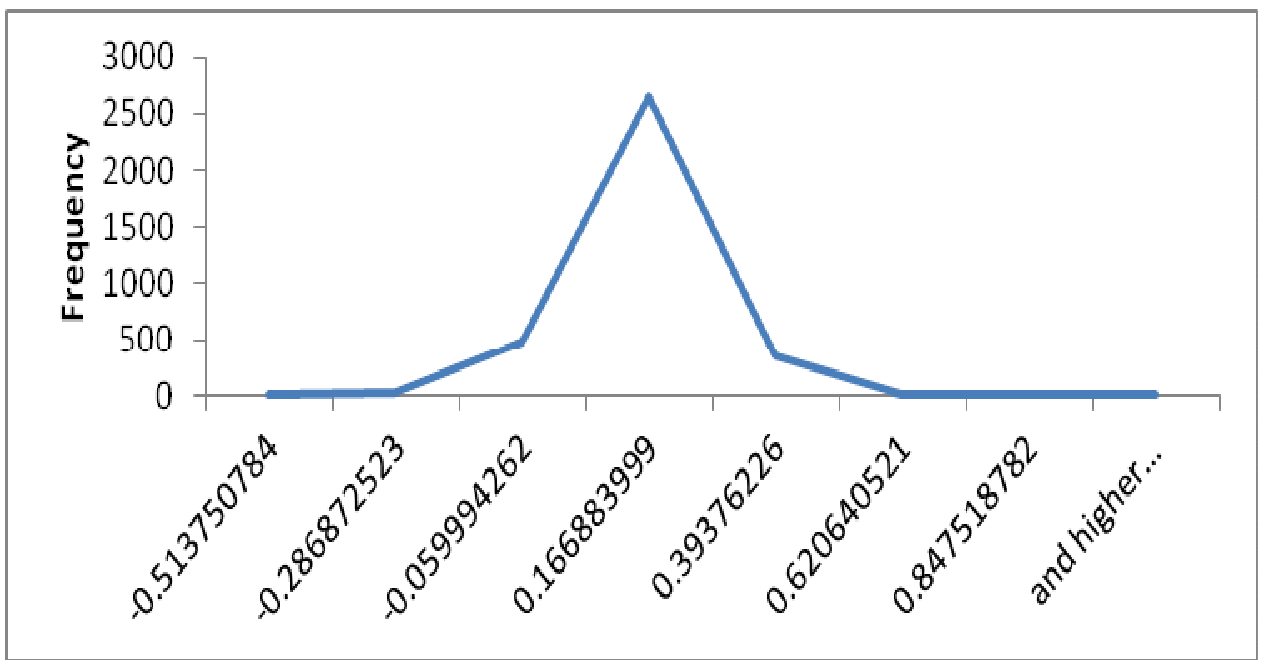

